Georgia State University

ScholarWorks @ Georgia State University

$2-5-2012$

\title{
Does Employing Undocumented Workers Give Firms a Competitive Advantage?
}

\author{
J. David Brown \\ Heriot-Watt University, jdavidbrown68@googlemail.com \\ Julie L. Hotchkiss \\ Georgia State University, julie.I.hotchkiss@atl.frb.org \\ Myriam Quispe-Agnoli \\ Federal Reserve Bank of Atlanta, myriam.quispe-agnoli@atl.frb.org
}

Follow this and additional works at: https://scholarworks.gsu.edu/uwrg_workingpapers

\section{Recommended Citation}

Brown, J. David; Hotchkiss, Julie L.; and Quispe-Agnoli, Myriam, "Does Employing Undocumented Workers Give Firms a Competitive Advantage?" (2012). UWRG Working Papers. 57.

https://scholarworks.gsu.edu/uwrg_workingpapers/57

This Article is brought to you for free and open access by the Usery Workplace Research Group at ScholarWorks @ Georgia State University. It has been accepted for inclusion in UWRG Working Papers by an authorized administrator of ScholarWorks @ Georgia State University. For more information, please contact scholarworks@gsu.edu. 
Working Paper 2012-2-5

February 2012

\section{Does Employing Undocumented Workers Give Firms a Competitive Advantage?}

J. David Brown

Heriot-Watt University

Julie L. Hotchkiss

Georgia State University

Myriam Quispe-Agnoli Federal Reserve Bank of Atlanta 


\title{
Does Employing Undocumented Workers Give Firms a Competitive Advantage?
}

\section{J. David Brown, Julie L. Hotchkiss, and Myriam Quispe-Agnoli}

\author{
Working Paper 2012-2 \\ February 2012
}

\begin{abstract}
Using administrative data from the state of Georgia, this paper finds that on average, among all firms, employing undocumented workers reduces a firm's hazard of exit by 19 percent. However, the impact varies greatly across sectors. In addition, a firm is at a distinct disadvantage if it does not employ undocumented workers but its rivals do. The advantage to employing undocumented workers increases as more firms in the industry do so. In addition, the advantage to a firm from employing undocumented workers decreases with the skill level of the firm's workers, increases with the breadth of a firm's market, and increases with the labor intensity of the firm's production process.
\end{abstract}

JEL classification: J15, C41, J42

Key words: Firm survival, illegal immigrants, hazard rates, survival analysis

\begin{abstract}
Valuable research assistance was provided by Nicole Baerg, Katharyn Rees, Navnita Sarma, and Menbere Shiferaw. The authors also benefited from consultations with Clark Burdick and Russell Hudson from the Social Security Administration and from discussions with participants at seminars at the Federal Reserve Bank of Atlanta, Oberlin College, and Heriot-Watt University. Additional helpful comments and suggestions were also received from Atanas Christev, Jacques Melitz, Giovanni Peri, and Mark Schaffer. The views expressed here are the authors' and not necessarily those of the Federal Reserve Bank of Atlanta or the Federal Reserve System. Any remaining errors are the authors' responsibility.
\end{abstract}

Please address questions regarding content to J. David Brown, School of Management and Languages, Heriot-Watt University, Edinburgh EH14 4AS, United Kingdom, 44131451 3493, j.d.brown@hw.ac.uk; Julie Hotchkiss, Research Department, Federal Reserve Bank of Atlanta, 1000 Peachtree Street, N.E., Atlanta, GA 30309, 404-4988198, julie.l.hotchkiss@atl.frb.org; or Myriam Quispe-Agnoli, Community and Economic Development Department, Federal Reserve Bank of Atlanta, 1000 Peachtree Street, N.E., Atlanta, GA 30309, 404-498-8930, myriam.quispe-agnoli@atl.frb.org.

Federal Reserve Bank of Atlanta working papers, including revised versions, are available on the Atlanta Fed's website at frbatlanta.org/pubs/WP/. Use the WebScriber service at frbatlanta.org to receive e-mail notifications about new papers. 


\section{Does Employing Undocumented Workers Give Firms a Competitive Advantage?}

\section{Introduction}

Firms may inherently wish to obey the law. But if breaking the law can give firms a competitive advantage, some may be tempted to do so. Several researchers have found a significant wage gap between documented and undocumented workers (e.g., Hotchkiss and Quispe-Agnoli 2009, Kassoudji and Cobb-Clark 2002, and Rivera-Batiz 1999). If this wage gap reflects more than productivity differences and costs from breaking the law, the employment of undocumented workers could reduce firm costs. We make use of administrative data from the state of Georgia to test whether employing undocumented workers actually gives firms a competitive advantage. ${ }^{1}$

The answer to this question has implications for immigration policy. If wages for both documented and undocumented workers are being determined in a competitive labor market, then greater restrictions of unauthorized immigration will unambiguously lead to higher wages, increased production costs, and likely higher prices paid by consumers. If firms employing undocumented workers, however, have a competitive advantage, the implication of tighter immigration policy would depend on the form that policy takes. In addition, understanding the mechanism driving the firm's decision process to employ undocumented workers will inform policy makers about potential opposition to successfully implementing proposed reforms and how those reforms might be structured to address concerns of employers.

There is a large literature on undocumented workers (see Hanson 2006 for a review), but

\footnotetext{
${ }^{1}$ It has often been claimed in the immigration debate that firms employing undocumented workers have an advantage over their competitors, but this has never been empirically tested. See, for example, Subcommittee on Workforce Protections (2006, pp. 25-26) or Cave (2008). Røed and Schøne (2006), however, do find that firms employing non-western immigrants have higher profits than firms employing western immigrants; they attribute this finding to discrimination.
} 
almost no prior studies have investigated undocumented worker employment at the firm level. One exception is Morales (1983), who conducts eight case studies of Los Angeles auto parts manufacturers. She finds that firms adapt to growing competition by employing undocumented workers, who are in plentiful supply in that area. The firms employing undocumented workers tend to be more labor intensive and face more variable demand (necessitating easily released labor). There is no previous work on the firm performance effects of employing undocumented workers. However, Champlin and Hake (2006) examine the increased need for short-term, lowskilled workers during the industrialization of the meatpacking industry from 1970-2002. They find that the presence of illegal immigrants within the factories reduced the bargaining power of shop workers and increased employer control.

The purpose of this paper is to determine whether there is any evidence of competitive advantage among firms that employ undocumented workers. If a competitive advantage is identified, this would be suggestive of monopsonistic discrimination; an absence of competitive advantage would suggest that the undocumented worker pay gap merely reflects productivity differences and costs of firms breaking the law. Results from the analysis in this paper will have implications for the impact of stricter immigration policies on product and labor markets, how effective those policies might be in modifying firm employment behavior, and from where opposition to or support for stricter policies might come. This paper does not address the overall welfare impact of firms employing undocumented workers. For example, the potential for consumers to pay lower prices as a result of firms employing cheaper labor (Cortes 2008) or the possibility that documented workers may earn lower wages as a result of the presence of undocumented workers (Hotchkiss and Quispe-Agnoli 2008) are issues not addressed here. 


\section{Theoretical Framework}

This section discusses how a wage gap could arise between documented and undocumented workers from a theoretical perspective. ${ }^{2}$ Depending on the source of the wage gap, firms employing undocumented workers may or may not receive a competitive advantage. The wage gap could simply reflect lower undocumented worker productivity. Undocumented workers may be systematically less educated, have less work experience, and have poor English language skills. ${ }^{3}$ Firms may also incur additional expenses from employing undocumented workers, such as fines, a loss of reputation, and costs of avoiding prosecution, so they may be willing to employ undocumented workers only if the wage is lower so as to compensate for such costs. Thus, a wage gap is not necessarily inconsistent with workers being paid their marginal products, and in such a scenario firms employing undocumented workers should receive no competitive advantage.

Discrimination against undocumented workers within firms that employ them could decrease productivity. If this isn't reflected in the wages paid to undocumented workers, firms employing them could have a competitive disadvantage. Perotin et al. (2003), for example, suggest that discriminated workers could be passed over for promotions and receive lower performance bonuses, not only reducing the workers' own productivity, but also generating negative spillovers for the firm as a whole (e.g., candidates for senior positions would be drawn from a smaller pool of workers). Undocumented workers may be expected to have lower future tenure in the firm either because they intend to return to their home country or because they may

\footnotetext{
${ }^{2}$ We implicitly assume firms know whether a worker is documented or not, though in reality firms must conduct costly background checks to be sure. Among firms not wishing to employ undocumented workers, rather than go to the trouble of doing a background check, it is common practice to avoid workers with characteristics associated with undocumented status, such as English language ability and ethnicity. It may thus be more accurate to label the two groups "suspected documented workers" and "suspected undocumented workers".

${ }^{3}$ Borjas and Katz (2005) find that Mexican immigrants to the U.S. are much less educated than U.S. natives. Unfortunately, the Georgia administrative data do not contain proxies for worker productivity such as age, education, or work experience.
} 
be deported. If expected tenure is low, the firm and the workers will have less of an incentive to invest in the match, also depressing productivity. Below we refer to the scenarios in this and the previous paragraph as productivity gap theories, as they assume that the wage gap can be explained by a productivity gap.

If, however, undocumented workers are just as productive as documented workers, and if firms are able to exercise monopsony power over undocumented workers as a result of low labor supply elasticities among these workers, then firms could pay these workers less than their marginal product and gain a competitive advantage. Undocumented workers need not even be as productive as documented workers for firms to gain an advantage; they only need to be willing to accept a wage that is lower than their marginal revenue product. The model of monopsonistic discrimination was developed by Robinson (1933) to describe a labor market in which two groups of equally productive workers (men and women) are paid different wages because they differ in their elasticities of labor supply. Robinson theorized that women were paid less than men because they were limited in their alternative employment options as a result of their husbands' employment situations. ${ }^{4}$ The source of the firm's monopsonistic power in the labor market derives from the behavior of workers, not from the degree of competition in the firm's product market. In other words, the presence of a large number of competitive firms does not preclude monopsonistic discrimination. In fact, intense product market competition will put additional pressure on an employer to take advantage of differential labor supply elasticities across workers.

Using the same data employed in this study, Hotchkiss and Quispe-Agnoli (2009) present empirical evidence that differences in labor supply elasticities between documented and

\footnotetext{
${ }^{4}$ Evidence of potential monopsonistic discrimination against women as a result of lower labor supply elasticities (relative to men) is provided by Hirsch et al. (2006) and Barth and Dale-Olsen (1999). Also see Bhaskar et al. (2002) for a review of evidence of monopsonistic competition more generally.
} 
undocumented workers accounts for about 30 percent of the observed within-firm wage differential. Fear of deportation and limited employment opportunities could help account for the lower labor supply elasticities among undocumented workers. In addition, Stark (2007) presents a compelling theoretical mechanism through which the work effort of undocumented workers is increased as their probability of deportation increases, which, in turn expands the wedge between undocumented worker productivity and their wage. Undocumented workers fearing deportation are unlikely to complain about low wages or poor employment environments. It is also not unreasonable to expect that the more employers to which undocumented workers expose themselves, the higher the risk of deportation. And it is likely that there are many firms that will simply refuse to employ undocumented workers and that undocumented workers are geographically constrained by the support (or lack) of social networks. All of these conditions reduce the employment opportunities of undocumented workers, ceteris paribus. ${ }^{5}$

In sum, the productivity gap theories do not predict any systematic patterns of undocumented worker employment across firms, and they imply that firms without undocumented workers will perform at least as well as those with them. The monopsonistic discrimination theory suggests that firms will enjoy a competitive advantage from employing undocumented workers at a below-marginal-product wage.

\section{Data}

The primary data used for the analyses in this paper are the Employer File and the Individual Wage File, compiled by the Georgia Department of Labor for the purposes of administering the state's Unemployment Insurance (UI) program. These data are highly confidential and strictly limited in their distribution. The data are available from the first quarter

\footnotetext{
${ }^{5}$ For further anecdotal and empirical evidence, see Semple (2008), Gibbons (2008), Bohon, et al. (2008), and Hotchkiss and Quispe-Agnoli (2009).
} 
of 1990 through the fourth quarter of 2006. The Employer File provides an almost complete census of firms. In the U.S. as a whole, the Employer File covers approximately 99.7 percent of all wage and salary workers (Committee on Ways and Means 2004). ${ }^{6}$ The establishment-level information includes the number of employees, the total wage bill, and the NAICS classification of each establishment. ${ }^{7}$ The 6-digit NAICS industry code and the county of location allow us to construct or merge in various industry- and county-level indicators.

The Individual Wage File is used to construct work force characteristics at the firm level. We take advantage of the longitudinal nature of the data to calculate the firm's age, employment variability, turnover rates, worker tenure, and most importantly, determination of when the firm ceases operation. Regrettably, the data set contains no information about workers' demographics or, more importantly, immigration status. The specific variables used for the analyses will be described in the empirical specification section below.

\section{A. Using SSNs to Identify Undocumented Workers}

Details of how the SSN is used to identify undocumented workers are contained in Appendix A. The abbreviated version is that there are some easily identifiable ways in which a SSN is determined to be invalid. We conclude that some of those reasons are either errors or the result of incomplete record keeping by the firm. We restrict our identification of undocumented workers to invalid SSN that are more likely to have been generated by the workers -- numbers that look valid, but are not. Robustness of the results to this restriction are tested and discussed in Appendix D. Workers with invalid SSNs for any other reason are considered neither undocumented nor documented and, thus, are excluded from the analysis; this will clearly

\footnotetext{
${ }^{6}$ Certain jobs in agriculture, domestic services, and non-profit organizations are excluded from UI coverage; excluded workers are not represented in the data.

${ }^{7}$ For multi-establishment firms, the NAICS assigned to the firm is that code corresponding to the establishment in which the firms employs the greatest number of workers.
} 
undercount the actual number of undocumented workers. However, all workers, regardless of SSN classification, are included in counts of aggregate firm employment. Fortuny et al. (2007) estimate that 4.5 percent of the workforce in Georgia was undocumented in 2004. In our sample 1.0 percent of workers are classified as undocumented in 2004, implying that the sample used for the analysis in this paper is capturing about 22 percent of all undocumented workers in the state of Georgia. Note that the identification process we use in this paper does not make any assumptions about whether the employer knows a worker is documented or undocumented, and that we are not after a count of the number of undocumented workers in Georgia, but merely a representation of a firm's hiring behavior.

Figure 1 illustrates the level and growth of undocumented workers in Georgia in the seven broad sectors with the highest incidence. The rate of growth seen in both the number and percent of undocumented workers identified using these data closely matches the rate of growth identified using different data sources and by other researchers. Again, details can be found in Appendix A.

[Figure 1 about here]

\section{B. Sample Means}

Table 1 compares some sample means across firms that do and do not employ undocumented workers. Many of the differences are as expected. For example, among firms that employ undocumented workers, a greater share of firms in the industry do so, indicating industry clustering; average wages, education, and tenure are lower among firms that employ undocumented workers; and there is greater churning among employing firms.

[Table 1 here]

We also see from Table 1 that firms employing undocumented workers tend to be larger, 
have multiple establishments, and are younger. We might have thought that older firms would have better developed access to undocumented worker supplies and therefore be more likely to employ undocumented workers than younger firms. However, perhaps younger firms are more likely to take risks or face greater pressures to improve their bottom line. Greater incidence of employing of undocumented workers by larger firms may reflect a more sophisticated record keeping process that increases the likelihood that any undocumented worker who is employed is also reported.

\section{Methodology}

The goal of the empirical analysis is to determine whether the practice of employing undocumented workers makes firms more successful against their rivals in a competitive product market. At its most fundamental level, the more efficiently a business transforms inputs into outputs the more successful it is -- greater efficiency, or productivity, translates into more profit for the owner(s). While the data at hand do not contain information about firms' profit levels, or even productivity, we are able to observe how long a firm survives. Firm survival has a wellestablished relationship with firm productivity. In his review of "What Determines Productivity?" Syverson (2011) states, "Far more than bragging rights [about having figured out their business] is at stake here: another robust finding in the literature--virtually invariant to country, time period, or industry--is that higher productivity producers are more likely to survive than their less efficient industry competitors. Productivity is quite literally a matter of survival for businesses."

The impact of employing undocumented workers on firm survival is estimated making use of standard matching techniques to control for the potential endogeneity of the decision to employ undocumented workers. As was seen in Table 1, there are a number of systematic 
differences in the observable characteristics of firms employing undocumented workers compared to firms that do not. This raises the possibility that the decision to employ undocumented workers is endogenous to a firm's survival; if not controlled, this endogeneity will bias the estimated impact of employing undocumented workers on firms' survival. We employ standard matching techniques to construct a synthetic control group that will produce unbiased survival analysis estimates. ${ }^{8}$ Details of the matching methodology are found in Appendix B.

\section{A. The Cox Proportional Hazard Model}

A standard Cox proportional hazard model is estimated to determine the impact of employing undocumented workers on firm survivability (performance). Girma et al. (2007) and Fajnzylber et al. (2005) are other examples of analyses that make use of matching techniques to construct a control sample with which to estimate the impact of an event or "treatment" on firms' survival. A hazard model framework allows us to quantify the timing of the exit, rather than the mere incidence, as would be the case in a simple probit or regression model (see Bhattacharjee et al. 2002; also see Disney et al. 2003).

Cox's regression does not require that a specific probability distribution for failure rates be assumed; it is a semi-parametric, generalized linear approach to survival analysis. The hazard function takes on the following form:

$$
h(t)=h_{0}(t) \exp \left(X_{i} \beta\right),
$$

where $h_{0}(t)$ is the baseline hazard that corresponds to the case where $X=0$. The impact of a one unit change in $X$ on the hazard of exiting (i.e., the probability of not surviving) is then calculated as:

\footnotetext{
${ }^{8}$ See Imbens (2004) for an exposition of matching methods.
} 


$$
\frac{\partial h(t)}{\partial X_{k}}=\exp \left[\partial\left(X_{i} \beta\right) / \partial X_{k}\right]-1 .^{9}
$$

Length of survival is calculated as the number of quarters a firm reports positive employment from the first quarter of treatment (first quarter employing undocumented workers), until the last quarter of existence (followed by four quarters of non-existence). Regressors include firm-specific characteristics, the firm's industry-specific characteristics, and whether or not the firm employs undocumented workers. We also include sector effects to control for sector-specific influences on firm performance (for example, see Samaniego 2009 and Cortes 2008). The firm's industry reflects the 2002 6-digit NAICS classification. The firm's sector is an aggregated grouping based on the NAICS. Appendix C contains a table of sector definitions.

\section{B. Firm-Specific Characteristics}

The most important characteristic of the firm for the purposes of this paper is whether or not the firm employs undocumented workers. A firm has to meet two criteria to be classified as "treated": (1) at least one worker with a worker-generated invalid SSN appears on the firm's payroll and (2) the firm has to employ at least one undocumented worker in at least 50 percent of the quarters observed in the data. Firms employing undocumented workers in less than 20 percent of observed quarters in the period after first employing undocumented workers or that never employ them are qualified to be control candidates; firms employing undocumented workers between 20 and 50 percent of the quarters after first employing them are excluded from the analysis. ${ }^{10}$

Other firm characteristics include age (and its square); employment (lagged four quarters, and its square); average quarterly wage among documented workers from the first quarter in the data set until four quarters prior to treatment and its square; the share of documented workers

\footnotetext{
${ }^{9}$ For example, see Cunningham (2007).

${ }^{10}$ Robustness of the results to this definition of a "treated" firm is considered in Appendix D.
} 
earning less than $\$ 3,000$ (in real terms) in a given quarter; this is approximately the full-time minimum wage, lagged four quarters; a dummy equal to one if the firm has multiple establishments; the firm's average rate of worker churning among its documented work force from the first quarter in the data set until four quarters prior to treatment, and also interacted with the treatment dummy (the firm's undocumented worker hiring behavior); average log tenure among documented workers from the first quarter in the data set until four quarters prior to the treatment quarter, and log of cumulative employment variability, which is calculated as the variance in total employment levels from the first quarter in the data set to four quarters prior to treatment.

Older firms should be less likely to exit, as they tend to have high productivity--otherwise they would have already exited. In addition, large firms tend to be more productive, so they should also have a lower exit propensity. ${ }^{11}$ Efficiency wage theory suggests that higher paying firms will also be more productive, thus less likely to exit (Akerlof and Yellen 1990), and a greater share of low-paid workers might be detrimental to performance because of greater wage dispersion within the firm (Winter-Ebmer and Zweimüller 1999).

A multi-establishment firm may be less likely to shut down since it can close individual establishments if necessary without shutting down completely. High worker churning is likely to add to the firm's labor costs, thus decreasing survivability. ${ }^{12}$ Having a work force with higher human capital would also make a firm more productive, thus reducing exit propensity. Higher average worker tenure reflects a higher level of firm-specific human capital. High employment variability may reflect a degree of instability, and thus a higher propensity to exit, or a firm that

\footnotetext{
${ }^{11}$ These relationships between firm age, size, and exit are predicted by the Jovanovic (1982) and Ericson and Pakes (1995) models of firm selection.

${ }^{12}$ Including this variable at least partially controls for the possibility that not all firms report their undocumented workers to the Department of Labor. As mentioned above, firms may be less likely to include undocumented workers on their UI wage report if the firm's separation experience has resulted in a higher UI tax rate.
} 
is nimble in adjusting to product demand, reducing the propensity to exit.

\section{Industry-, Sector-, and County-Specific Characteristics}

Growth of the firm's industry over the previous year and growth of the firm's sector in the firm's county, as measured by annual employment growth through the previous quarter (calculated using the Davis and Haltiwanger 1992 method), are included as measures of the strength in the firm's industry overall and in the firm's broader sector more geographically specific to the firm's location. We include industry level growth, as opposed to firm growth since we expect firm growth is more likely endogenous. Industry growth should capture exogenous forces affecting all firms in the sector.

Regressors are also included to account for overall economic demand and consumption that the firm might face in its locality: county population growth (annual growth through the preceding quarter); log county per-capita income (lagged one year); and population density (lagged one year). In addition, the proportion of total public school enrollment that is Hispanic (lagged one year) in included as a proxy for the availability of undocumented workers. A threedigit industry fixed effect is also included as a first-stage control. The county-level Hispanic enrollment variable is measured only in October in each year and is assigned to all quarters in the following calendar year. ${ }^{13}$

Just as a firm's own employment of undocumented workers could give it a comparative advantage, undocumented employment by competitors could place the firm at a disadvantage. To test this, we include a variable measuring the proportion of other firms in the firm's 6-digit NAICS industry that employ undocumented workers (lagged four quarters), as well as interacting this regressor with the treatment dummy.

The competitive advantage of employing undocumented workers may vary with the

\footnotetext{
${ }^{13}$ Hispanic enrollment is available starting in 1995 and thus 1995 values are used for each county for prior years.
} 
geographic size of the product market. In markets where firms supply a geographically broad product market, firms may have competitors with access to low-cost labor that is both legal and plentiful in developing countries (for example, see Preston 2007). In such cases, employing undocumented workers may be particularly important for keeping up with competitors. To measure geographic market size, we make use of a modified Duncan index of dissimilarity, lagged four quarters (Duncan and Duncan 1955); this measure of dissimilarity is also interacted with the treatment dummy.

The skill level of workers in the firm's industry and the intensity with which firms employ workers in their production process may affect the importance of employing undocumented workers to the firm's survivability. Industry skill and labor intensity are included as additional regressors (lagged four quarters); their construction is described in Appendix B. Both of these regressors are interacted with the treatment dummy to assess whether the impact of employing undocumented workers on firm survival varies by skill level of the firm or by labor intensity of the production process.

\section{Results}

\section{A. Probability of Treatment and Matching}

Before estimating the impact of employing undocumented workers on the survival of a firm, the issue of potential selection bias must be resolved. Results from estimating the probability of employing undocumented workers are reported in Appendix Tables B1-B4. Some of the influences of regressors vary across sectors, but generally a firm's propensity to employ undocumented workers increases with firm size; higher churning and employment variability (more weakly); greater county-level population growth, per capita income, population density, and Hispanic enrollment. The increased propensity with churning suggests that employing 
undocumented workers may be born out of a need for flexibility in the firm's production process; this was also documented by Morales (1983). Also consistent with higher churning at firms that employ undocumented workers, firms whose workers have longer tenure are generally less likely to employ undocumented workers. Treated firms are matched to controls based on their

propensity score ratio (details described above); Table B5 shows the number of treated firms and matched controls, broken down by propensity score quintile. There are sufficient numbers of treated and matched control firms in each quintile to produce reliable estimates. Table B6 shows the distribution of treated and control firms across broad sectors. The relative concentration of treated and control firms across sectors is fairly consistent.

Several balancing tests were performed which are discussed in detail in Appendix B and whose results are reported in Tables B7 and B9. The bottom line from the balancing tests is that the matching procedure improved the balance of the treated and non-treated samples considerably.

\section{B. Baseline Hazards}

Figure 2 produces the baseline hazards for three groups of firms: the treated firms, all controls (all firms not employing undocumented workers), and the matched controls (firms not employing undocumented workers matched to treated firms). We learn two things from this figure. First, the baseline hazards of the matched controls are nearly identical to those of all controls. The second thing we learn is that the baseline hazards among treated firms is higher than those of the controls early in a firm's employing experience, but lower than that of controls after surviving about 28 quarters. In other words, without controlling for any characteristics, firms employing undocumented workers are more likely to exit, on average, soon after treatment and less likely to exit later on than firms not employing undocumented workers. This would 
suggest that employing undocumented workers puts firms at a disadvantage early on, but eventually at an advantage. The possibility of a time-varying treatment effect will be investigated.

[Figure 2 about here]

\section{Survival Analysis}

Table 2 contains parameter coefficients from the Cox proportional hazard estimation for three different specifications. The first set of estimates (A) does not include any interactions with the firm's undocumented worker hiring behavior (UNDOC). This specification gives us the overall, average impact across all firms and sectors of employing undocumented workers. The second specification (B) interacts employing undocumented workers with industry sector in order to see if the impact of employing undocumented workers differs across sectors. The third specification (C) interacts employing with a number of industry and firm specific characteristics in order to dissect these broad sector differences.

[Table 2 about here]

Larger firms have a lower hazard of exiting; firms with a higher average wage (more skilled workers) and tenure among documented workers have a lower hazard of exiting; firms with high employment variability (holding churning constant) have a higher hazard of exiting; and firms with higher churning (holding employment variability constant) have an increased hazard of exiting, suggesting that both employment variability and churning are costly to firms. The insignificance of the influence of being a multi-establishment firm is a puzzle, as one typically finds that firms with multiple units are less likely to fail (for example, see Bernard and Jensen 2007, Disney et al. 2003, and Dunne et al. 1989). Perhaps this result is a consequence of having data on firms located in Georgia only. Multi-establishment firms are obviously more 
likely than single-establishment firms to have establishments outside of the state of Georgia and an exit of the Georgia establishment does not necessarily mean that the rest of the firm (those establishments outside of Georgia) has also failed. The higher exit rates among older firms might also appear as a mystery as older firms have learned how to survive (through, it's typically argued, greater productivity). However, if we remove worker tenure from the estimation, the coefficient on age becomes negative, suggesting that worker tenure is picking up the productivity effects that would typically be captured by the firm's age. Among the geographic controls, firms located in more densely populated counties and counties that are faster growing are significantly less likely to exit. However, firms located in counties with higher per capita income or larger populations of Hispanics are more likely to exit.

Now we turn to the main focus of the estimation--the impact of employing undocumented workers on firm survival. Specification (A) suggests that employing undocumented workers reduces an average firm's hazard of exit by 19 percent, taking the average hazard rate from 0.28 to $0.23 .^{14}$ However, this overall average impact varies considerably across broad sectors; specification (B) indicates that employing undocumented workers statistically significantly reduces the hazard rate of exit among firms in Transportation \& Utilities (by -7\%), Professional \& Business Services (by $-3 \%$ ), Leisure \& Hospitality (by $-6 \%$ ), and Other Services (by $-6 \%) .{ }^{15}$ Employing undocumented workers significantly increases a firm's hazard of exiting in the Financial Services (by $+6 \%$ ), Information (by $+18 \%$ ), and Education $\&$ Health (by $+9 \%$ ) sectors; these are sectors that employ relatively few undocumented workers and are likely to have a more highly skilled workforce. Interestingly, there is an insignificant impact on exits from employing

\footnotetext{
${ }^{14}$ For example, the first overall average impact of employing undocumented workers is calculated as $-0.189=e^{-0.21}-1$. These sector-specific effects are calculated using results from specification (B).

${ }^{15}$ These marginal effects are calculated by taking the difference in hazard rates between the treated and non-treated average baselines in each sector.
} 
undocumented workers in Agriculture, Construction, and Manufacturing. These are sectors that, behind Leisure and Hospitality, have the largest shares of firms employing undocumented workers.

The interaction terms in specification (C) suggest how the different characteristics of firms and industry sectors might be contributing to the differences in the impact of employing undocumented workers. For example, the broader a firm's market (the more concentrated is employment in an industry by county), the greater advantage the firm has in employing undocumented workers. A one standard deviation increase in employment concentration decreases the hazard rate of a firm that employs undocumented workers by an additional 12 percent. This might be expected since a firm serving a broader market may have to compete with firms from abroad that have access to even lower-cost labor; being able to employ lower paid undocumented workers in Georgia will have an even greater advantage for these firms, compared to firms that are only competing locally. This result could also arise if the concentration of many employers in close proximity allowed firms to benefit from an established supply chain of undocumented workers -- an agglomeration argument.

Additionally, the impact of other firms employing undocumented workers depends on the employment practice of the firm. If a firm does not employ undocumented workers, but others in the industry do, the firm's hazard of exit is higher as the share of employing firms increases. This is consistent with anecdotal evidence obtained from interviews with firms and from Congressional testimony, in which firms report that they feel a need to employ undocumented workers to stay competitive, because competitors employing undocumented workers are able to undercut their prices. ${ }^{16}$

\footnotetext{
${ }^{16}$ For example, see the testimony of Charles Shafer, carpenter from Lawrenceville, GA (Subcommittee on Workforce Protections of the Committee on Education and the Workforce, 2006, pp. 25-6).
} 
However, if the firm does employ undocumented workers, more other firms also employing reduces the firm's hazard even more. Among firms employing undocumented workers, a one percentage point increase in the share of firms in the industry employing undocumented workers lowers a firm's hazard rate an additional four percent. This suggests there may be fixed costs associated with bringing undocumented workers into an industry, either because of the costs associated with establishing a supply chain of undocumented workers from their home country to Georgia, or because the first firms to employ incur the costs of industryspecific training of workers. As more firms employ undocumented workers, the opportunities to piggyback on the established supply chain and training increase. It also may be the case that as more firms employ undocumented workers, the likelihood of any one firm getting caught declines, increasing survivability.

A firm with a production process that is more labor intensive appears to have a greater advantage to employing undocumented workers than a firm with a less labor intensive production process. This makes sense, as a more labor-intensive production process means that labor cost is a greater share of the total, and the firm stands to gain more by reducing that portion of the cost of production. A one percentage point increase in a firm's labor intensity decreases its hazard of exiting when employing undocumented workers by an additional three percent.

It also stands to reason that firms with a lower skilled work force would gain the greatest advantage from employing undocumented workers, who tend to be among the lowest skill in the labor market (for example see Borjas and Katz 2005). A one percentage point decrease in the share of workers in the firm's industry with a college education decreases the firm's hazard by an additional five percent.

As Morales (1983) found in her case study of automobile manufacturers in Los Angeles, 
firms experiencing a high degree of workforce churning in this analysis benefit significantly from employing undocumented workers. Employing undocumented workers appears to offer firms needing to replace workers frequently a degree of employment flexibility that is highly beneficial.. A one standard deviation increase in the rate of churning increases the advantage of employing undocumented workers by 29 percent; this is the most important firm characteristic modifying the impact of employing undocumented workers on the firm's hazard rate of exit.

As in any empirical analysis, several decisions have been made regarding specification and definitions, particularly as they relate to how one designates a "treated" firm and which workers with invalid SSNs are deemed "undocumented" while excluding the others. Appendix D contains the results of various robustness exercises. The bottom line is that the results presented here are quite robust.

\section{Time-varying Treatment Effect}

The baseline estimations assume that the treatment effect, or impact of employing undocumented workers on the hazard of exit, is the same regardless of the time since treatment. However, the baseline hazard rates depicted in Figure 2 suggest that firms experience a higher hazard rate of exiting when they initially employ undocumented workers and that the advantage only appears over time. Why would firms initially employ undocumented workers if it puts them at a disadvantage?

One possibility is found in the strategic management literature. Many studies document an advantage to firms being an early market entrant. Early entrants can pre-empt resources through geographic positioning, molding consumer perceptions, or cornering technology, for example (see Lieberman and Montgomery 1998). There is also a possibility that new entrants are willing to undertake short-term risk for longer-term payoff, or that later entrants can take 
advantage of supply networks and the availability of industry-specific human capital, as has been illustrated in the agglomeration literature (Kutzbach 2010, Helsley 1990, and Strange 1990). We find some evidence that in the case of employing undocumented workers, being an early entrant (employing undocumented workers when few other competitors do so) is a risky endeavor, promises longer-term payoffs, and that later entrants benefit from "agglomeration" (other firms in the industry already employing undocumented workers).

The specifications in Table 3 are re-estimated interacting the UNDOC regressor (and its interactions) with time since treatment. A graphical presentation of these results is more informative than a tabular one. Figure 3 shows that, indeed, initially employing undocumented workers increases a firm's hazard, but then works to decrease it. The median firm with regard to the amount of time since first employing undocumented workers can expect a statistically significant reduction in its exit hazard of about 27 percent. So, clearly, there is a significant longer-term payoff to that initial potentially risky decision to employ undocumented workers.

[Figure 3 about here]

In addition, Figure 4 illustrates that once an industry has established supply lines and acquires the cultural and language knowledge required to manage an undocumented workforce, the benefit of a reduced hazard rate from employing undocumented workers is significant and immediate ${ }^{17}$ This result is also consistent with finding a reduction in hazard rate among firms employing undocumented workers in those sectors in which the share of firms employing is relatively large (Professional \& Business Services, Leisure \& Hospitality, and Other Services), but a higher hazard rate among firms that employ in sectors where the share of firms that are also employing is relatively low (Financial Services, Information, and Education \& Health).

\footnotetext{
${ }^{17}$ The marginal effects in Figure 4 are as large as they are because we are illustrating the extreme cases of zero and one hundred percent employment of undocumented workers by other firms.
} 
[Figure 4 about here]

Figure 5 presents some evidence that initial employment of undocumented workers is either a risky undertaking or that firms that choose to employ undocumented workers initially do so in the hopes of moderating a volatile period in their establishment's life; a strategy, if they make it through the volatile period, that appears to pay off. This figure plots the standard deviation of documented worker employment growth around the time of the treated firms' treatment (initial employment of undocumented workers).

[Figure 5 about here]

\section{E. What Does a Firm Know and Does it Matter?}

The hypothesis that employing undocumented workers contributes positively to the economic performance of the firm requires three assumptions. The first is that the employer knows the worker being employed is undocumented. Second, the worker has limited employment opportunities and is thus likely to accept a wage below his marginal revenue product. And third, the expected benefit to the firm of such a hire exceeds the expected cost of breaking the law. Support for the first assumption comes from a number of sources. Up to 60 percent of Mexicans in the U.S. are undocumented (see footnote 16), and thus ethnic Hispanic characteristics and limited English skills are features employers can use to identify which workers are likely undocumented; there is no need to carefully scrutinize the presented SSN to determine with a high degree of accuracy whether a worker is undocumented.

Additionally, there is a significant amount of evidence that undocumented workers have limited employment opportunities. For example, Bohon, et al. (2008) document the transportation difficulties of newly arriving Latinos to Georgia, many of whom are undocumented workers. In addition, Semple (2008) offers anecdotal evidence that 
undocumented workers are at the mercy of their employers. An undocumented worker reported to Semple that an employer refused to pay him about $\$ 1,000$ he was owed for work performed, but that, "fear [of being deported] kept my mouth shut." And, lastly, Hotchkiss and QuispeAgnoli (2009) provide empirical evidence that the labor supply of undocumented workers is, indeed, less sensitive to wages than that of documented workers.

The third assumption that the expected benefit from employing exceeds the expected cost of breaking the law is supported by evidence of low probabilities of an employer getting caught and of the low fines if they do get caught (at least prior to 2008). These probabilities are likely to vary by industry and firm characteristics (such as firm size), but on the whole are considered to be negligible, especially in a non-border state. For example, CBO (2010) reports that 91 percent of all apprehensions of unauthorized immigrants occur at the border. In addition, prior to 2006, workforce enforcement did not figure very large in efforts to combat unauthorized immigration (CBO 2006, also see Jordan 2011). A firm's decision to employ undocumented workers would thus depend on the assessments of costs and benefits to their own economic outcome and the ethics of the person making the employment decision. There is a possibility that firms that employ undocumented workers also have a higher propensity to break other laws; it's unclear how this propensity might be expected to affect firm survival.

\section{Conclusion}

The results of the analysis in this paper indicate that overall, firms employing undocumented workers experience a competitive advantage over firms that do not employ undocumented workers. On average, employing undocumented workers reduces a firm's hazard of exiting by 19 percent relative to the baseline exit rate. However, the impact varies greatly across broad sectors and across firm and sector characteristics. Firms with greater worker 
churning and those in sectors with a greater share of other firms employing undocumented workers, a more geographically concentrated product market, a production process that is highly labor intensive, or in a sector with a greater share of lower skilled workers are the ones experiencing a greater advantage from employing undocumented workers. Firms operating in the Transportation \& Utilities, Professional \& Business Services, Leisure \& Hospitality, and Other Services sectors appear to benefit the most from employing undocumented workers. And employing undocumented workers in some sectors (Financial Services, Information, and Education \& Health) actually increases the hazard rate of exit for firms in those sectors.

Evidence was presented that the impact of employing undocumented workers varies over the time since the firm first employs undocumented workers; the average firm does not experience a reduction in its hazard rate until five quarters after first employing undocumented workers. Further investigation shows that this initial penalty to employment of undocumented workers is only in circumstances where few other firms employ undocumented workers. This reinforces the notion of a first-mover penalty where it takes time for a sector to establish effective employment practices and a worker pipeline in order to reap the benefits of, basically, breaking the law.

Others have identified a sizeable wage gap between documented and undocumented workers, with undocumented workers being paid about 30 percent less than documented workers (e.g., Hotchkiss and Quispe-Agnoli 2009, Kassoudji and Cobb-Clark 2002, and Rivera-Batiz 1999). Whether this wage gap results in cost savings for employers, thus improving their competitiveness, depends on its source. If the wage gap compensates for lower productivity among, or higher risk from employing undocumented workers, then firms employing undocumented workers should experience no competitive advantage. If, on the other hand, firms 
are able to distinguish between groups of workers and one group has a lower labor supply elasticity, the firm can gain a competitive advantage by paying those workers a wage below their marginal revenue product. This wage-setting practice is referred to as monopsonistic discrimination. The analysis in this paper provides evidence consistent with employers' ability to sustain monopsony power over undocumented workers in some economic sectors, and especially when other firms in the sector are also employing undocumented workers.

From an economic perspective, any policy that reduces the supply of undocumented workers (e.g., through tougher border and worksite enforcement) will raise firms' production costs and, likely, prices paid by consumers in those sectors employing larger shares of undocumented workers (for example, see Cortes 2008).

From a political perspective, the results of this paper provide strong predictions about the sources of lobbying about and potential effectiveness of immigration policies designed to reduce the supply of undocumented workers. Resistance to tougher enforcement is likely to come from employers in industries where undocumented employment is most advantageous, such as professional \& business services, other services, leisure \& hospitality, and from industries where firms are geographically concentrated. Groups representing documented workers in those same sectors are likely to call for tougher enforcement due to their depressed wages resulting from undocumented employment. In addition, local initiatives to enforce immigration law are likely to be more effective at curbing employment of undocumented workers within geographically segmented industries, as firms don't face the same competitive pressures from foreign competition.

The identification of a competitive advantage accruing to certain firms that employ undocumented workers suggests that they are exercising some monopsony power in the labor 
market for these workers. Consequently, if immigration policies predicated on workers' rights and moral obligation (see Gibbons 2008 and Greenhouse 1999) are successful in forcing firms to treat undocumented workers in the same way as documented workers, their competitive advantage may disappear, lowering demand for undocumented workers. 


\section{References}

Akerlof, George A., and Janet L. Yellen. 1990. "The Fair Wage-Effort Hypothesis and Unemployment." Quarterly Journal of Economics 105(2) (May): 255-83.

Barth, Erling, and Harald Dale-Olsen. 1999. "Monopsonistic Discrimination and the Genderwage Gap," Working Paper no. W7197, NBER, Cambridge, MA.

Bernard, Andrew B. and J. Bradford Jensen. 2007. "Firm Structure, Multinationals, and Manufacturing Plant Deaths." The Review of Economics and Statistics 89(2): 193-204.

Bhaskar, V., Alan Manning, and Ted To. 2002. "Oligopsony and Monopsonistic Competition in Labor Markets." Journal of Economic Perspectives 16(2) (Spring): 155-74.

Bhattacharjee, A.; Chris Higson; Sean Holly; and Paul Kattuman. "Macro Economic Instability and Business Exit: Determinants of Failures and Acquisitions of Large UK Firms." London Business School Working Paper No. 02-034 (5 March 2002).

Bohon, Stephanie A.; Katherine Stamps; and Jorge H. Atiles. "Transportation and Migrant Adjustments in Georgia." Population Research Policy Review 27 (2008): 273-91.

Borjas, George J., and Lawrence F. Katz. 2005. "The Evolution of the Mexican-Born Workforce in the United States." Working Paper no. 11281, NBER, Cambridge, MA.

Bovbjerg, Barbara D. 2006. Social Security Numbers: Coordinated Approach to SSN Data Could Help Reduce Unauthorized Work, Testimony before the Subcommittees on Social Security and on Oversight, Committee on Ways and Means, House of Representatives, GAO-06-458T, http://www.gao.gov/new.items/d06458t.pdf, (accessed 15 December 2008).

CBO. Immigration Policy in the United States, Pub. No. 2499 (February 2006).

CBO. Immigration Policy in the United States: An Update, Pub. No. 4160 (January 2010).

Champlin, Dell, and Eric Hake. 2006. "Immigration as Industrial Strategy in American Meatpacking." Journal of Political Economy 18(1) (January): 49-69.

Committee on Ways and Means, House of Representatives. 2004. Greenbook, WMCP 108-6, Section 4 (April).

Cortes, Patricia. 2008. "The Effect of Low-skilled Immigration on U.S. Prices: Evidence from CPI Data." Journal of Political Economy 116(3): 381-422.

Cunningham, Christopher. 2007. "Growth Controls, Real Options and Land Development." Review of Economics and Statistics 89(2) (May): 343-58. 
Davis, Steven J., and John C. Haltiwanger. 1992. "Gross Job Creation, Gross Job Destruction, and Employment Reallocation." Quarterly Journal of Economics 107(3) (August): 81963.

Disney, Richard; Jonathan Haske, and Ylva Hedan. 2003 "Entry, Exit, and Establishment Survival in UK Manufacturing." Journal of Industrial Economics 51(1) (March): 91-112.

Duncan, Otis D. and Beverly Duncan. 1955. "A Methodological Analysis of Segregation Indexes." American Sociological Review 20, (April): 210-17.

Dunne, Timothy; Mark J. Roberts; and Larry Samuelson. 1989. "The Growth and Failure of US Manufacturing Plants." Quarterly Journal of Economics 104(4): 671-98.

Ericson, Richard and Ariel Pakes. 1995. "Markov-Perfect Industry Dynamics: A Framework for Empirical Work." Review of Economic Studies 62(1) (January): 53-82.

Fajnzylber, Pablo; William F. Maloney; and Gabriel V. Montes Rojas. "Releasing Constraints to Growth or Pushing on a String? The Impact of Credit, Training, Business Associations, and Taxes on the Performance of Mexican Micro-Firms." World Bank Policy Research Working Paper No. 3807 (December 2005).

Fortuny, Karina, Randy Capps, and Jeffrey S. Passel. 2007. "The Characteristics of Unauthorized Immigrants in California, Los Angeles County, and the United States," Mimeo. Washington, D.C.: The Urban Institute (March).

Gibbons, Margaret. 2008. "Labor Union Criticizes the Handling of Immigrants." TimesHerald.com (6 August), $<$ http://www.timesherald.com/site/printerFriendly.cfm?brd=1672\&dept_id=33380\&news id=19894880>, (accessed 6 August 2008).

Girma, Sourafel; Holger Gorg; and Eric Strobl. "The Effects of Government Grants on Plant Survival: A Micro-econometric Analysis." International Journal of Industrial Organization 25(4) (August 2007): 701-20.

Greenhouse, Steven. 1999. "U.S. to Expand Anti-discrimination Rights for Illegal Immigrants Working in This Country." nytimes.com (28 October) $<$ http://query.nytimes.com/gst/fullpage.html?res=9C00E7DE1138F93BA15753C1A96F958260\&s $\mathrm{cp}=12 \& \mathrm{sq}=$ undocumented $\% 20$ worker\%20rights\&st=cse $>$, (accessed 24 October 2008).

Hanson, Gordon H. 2006. "Illegal Migration from Mexico to the United States." Journal of Economic Literature 44(4) (December): 869-924.

Helsley, Robert W. "Knowledge Production in the CBD." Journal of Urban Economics 28(3) (November1990): 391-403. 
Helsley, Robert W. and William C. Strange. "Matching and Agglomeration Economies in a System of Cities. Regional Science and Urban Economics 20(2) (September 1990): 189212.

Hirsch, Boris, Thorsten Schank, and Claus Schnabel. 2006. "Gender Differences in Labor Supply to Monopsonistic Firms: An Empirical Analysis Using Linked Employer-Employee Data from Germany." Friedrich-alexander-Universitat Erlangen-Nurnberg Discussion Papers No. 47, (November).

Hoefer, Michael, Nancy Rytina, and Christopher Campbell. 2007. "Estimates of the Unauthorized Immigrant Population Residing in the United States: January 2006," Population Estimates. Washington, D.C.: US Department of Homeland Security, Office of Immigration Statistics, (August).

Hotchkiss, Julie L., and Myriam Quispe-Agnoli. 2009. "Employer Monopsony Power in the Labor Market for Undocumented Workers." Federal Reserve Bank of Atlanta Working Paper 2009-14(c), (December).

Hotchkiss, Julie L. and Myriam Quispe-Agnoli. 2008. "The Labor Market Experience and Impact of Undocumented Workers." Federal Reserve Bank of Atlanta Working Paper \#2008-7c (June).

Huse, James G. 2002. Congressional Response Report: Status of the Social Security Administration's Earnings Suspense File A-03-03-23038 (November) http://www.ssa.gov/oig/ADOBEPDF/A-03-03-23038.pdf, (accessed 11 December 2008).

Imbens, Guido W. 2004. "Nonparametric Estimation of Average Treatment Effects Under Exogeneity: A Review." Review of Economics and Statistics 86(1) (February): 4-29.

Johnson, Mary. 2007. "The Growing Cost of Illegal Immigrants to Social Security: Unprecedented Growth in Social Security's 'Earnings Suspense File." Mimeo (March) $<$ http://www.tscl.org/NewContent/102880.asp> (accessed 11 December 2008).

Jordan, Miriam. "Crackdown on Illegal Workers Grows." WSJ.com (20 January 2011) $<$ http://online.wsj.com/article/SB10001424052748703951704576092381196958362.html>, accessed 1 April 2011.

Jovanovic, Boyan. 1982. "Selection and Evolution of Industry." Econometrica 50(3) (May): 649670.

Kossoudji, Sherrie A. and Deborah A. Cobb-Clark. "Coming out of the Shadows: Learning about Legal Status and Wages from the Legalized Population." Journal of Labor Economics 20(3) (2002): 598-628.

Kutzbach, Mark J. "Access to Workers or Employers? An Intra-urban Analysis of Plant Location Decisions." CES Working Paper 10-21 (September 2010). 
Lieberman, Marvin B. and David B. Montgomery. "First-mover (Dis)advantages: Retrospective and Link with the Resource-Based View." Strategic Management Journal 19 (1998): 1111-25.

Morales, Rebecca. 1983. "Transitional Labor: Undocumented Workers in the Los Angeles Automobile Industry." International Migration Review 17(4) (Winter): 570-596.

Passel, Jeffrey S. and D'Vera Cohn. 2009. A Portrait of Unauthorized Immigrants in the United States. Pew Hispanic Center: Washington, D.C. (April).

Pena, Anita Alves. 2010. "Legalization and Immigrants in U.S. Agriculture." The B.E. Journal of Economic Analysis \& Policy 10(1), Article 7.

Perotin, Virginie, Andrew Robinson, and Joanne Loundes. 2003. "Equal Opportunities Practices and Enterprise Performance: A Comparative Investigation on Australian and British Data." International Labour Review 142(4) (December): 471-505.

Preston, Julia. 2007. "Short on Labor, Farmers in U.S. Shift to Mexico." nytimes.com, (5 September), <http://www.nytimes.com/2007/09/05/us/05export.htm>, (accessed 17 October 2008).

Rivera-Batiz, Franciso. "Undocumented Workers in the Labor Market: An Analysis of the Earnings of Legal and Illegal Mexican Immigrants in the United States." Journal of Population Economics 12(1) (February 1999): 91-116.

Robinson, Joan. 1933. The Economics of Imperfect Competition, Macmillan: London.

Røed, Marianne and Pål Schøne. 2006. "Does High Product Market Competition Benefit Immigrants?" Mimeo, Institute for Social Research (February).

Rosenbaum, Paul R. and Donald B. Rubin. 1985. "Constructing a Control Group Using a Multivariate Matched Sampling Method that Incorporates the Propensity Score." The American Statistician 39(1) (February): 33-8.

Samaniego, Roberto M. 2009. "Entry, Exit, and Investment-Specific Technical Change." American Economic Review 100(1): 164-92.

Semple, Kirk. 2008. "With Economy, Day Laborer Jobs Dwindle." nytimes.com (20 October), $<$ http://www.nytimes.com/2008/10/20/nyregion/20laborers.html?partner=rssnyt $>$, (accessed 20 October 2008).

Smith, Jeffrey and Petra Todd. 2005. "Rejoinder.” Journal of Econometrics 125(1/2) (March/April): 365-75. 
Stark, Oded. 2007. "Work Effort, Moderation in Expulsion, and Illegal Migration." Review of Development Economics 11(4) (February): 585-90.

Subcomittee on Workforce Protections of the Committee on Education and the Workforce, U.S. House of Representatives, Field Hearing in Gainesville, Georgia. 2006. "Immigration: Economic Impact on American Workers and their Wages.” Washington: U.S. Government Printing Office, Serial No. 109-52, (August 14) $<$ http://bulk.resource.org/gpo.gov/hearings/109h/29475.txt>, (accessed 30 July 2008).

Syverson, Chad. "What Determines Productivity?" Journal of Economic Literature 49(2) (2011): 326-65.

U.S. Department of Housing and Urban Development. 1990. "Disclosure and Verification of Social Security Numbers (SSNs) for the Section 235 Program." Mortgagee Letter 90-39, (9 November), http://209.85.165.104/search?q=cache:5VRIgv1oFQYJ:www.fha.gov/reference $/ \mathrm{ml} 1990 / 9$ $0-39 \mathrm{ml} . \mathrm{doc}+$ pocketbook + social + security + numbers $\& h \mathrm{l}=\mathrm{en} \& \mathrm{ct}=\mathrm{clnk} \& \mathrm{~cd}=9 \& \mathrm{gl}=\mathrm{us}$, (accessed 20 September 2007).

Winter-Ebmer, Rudolf and Josef Zweimüller. 1999. "Intra-firm Wage Dispersion and Firm Performance." Kyklos 52(4) (May): 555-72. 
Figure 1.

Percent of workers that is undocumented by broad industry, 1990:1 - 2006:4

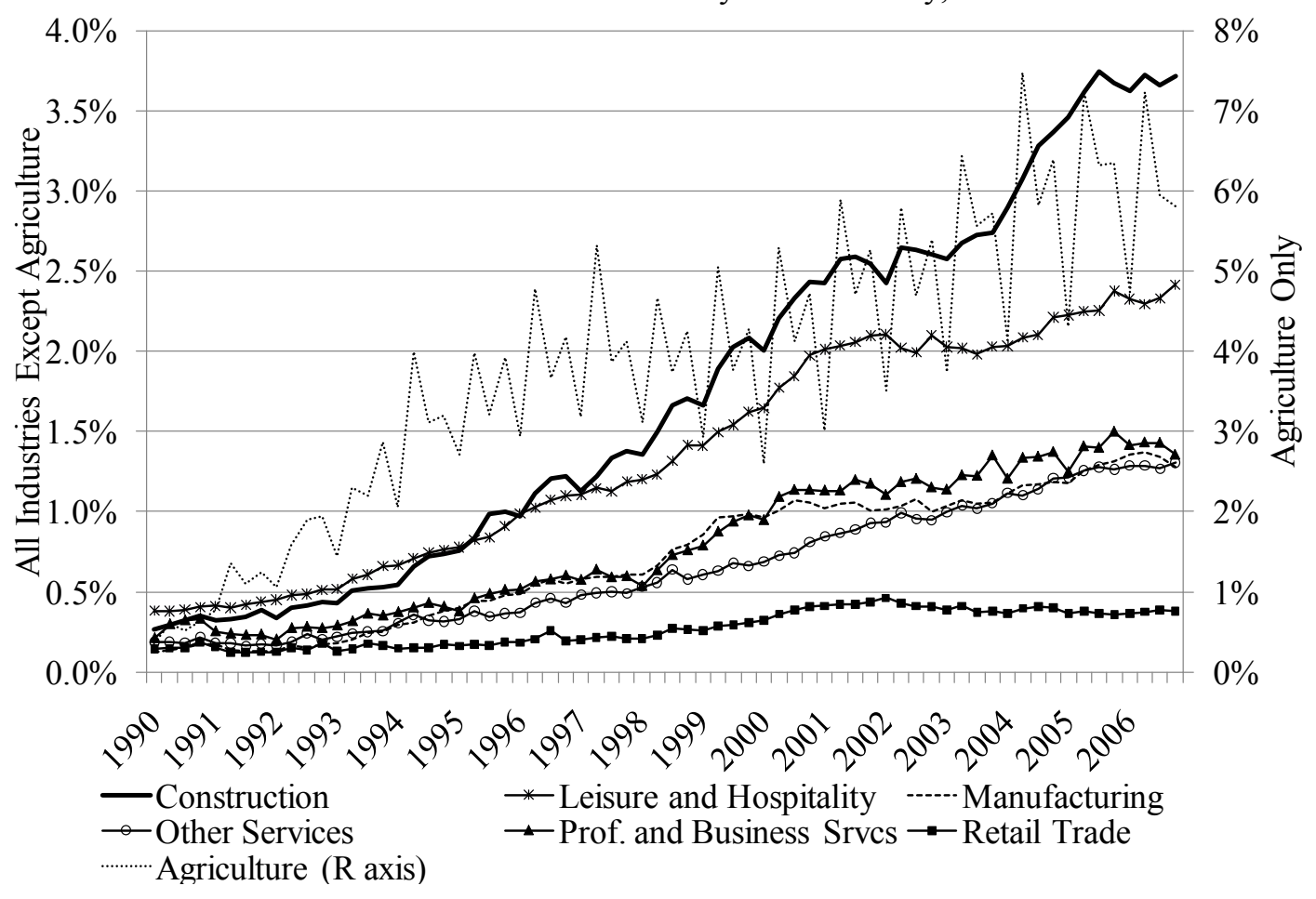

Figure 2. Baseline hazards for treated firms, matched controls, and all controls.

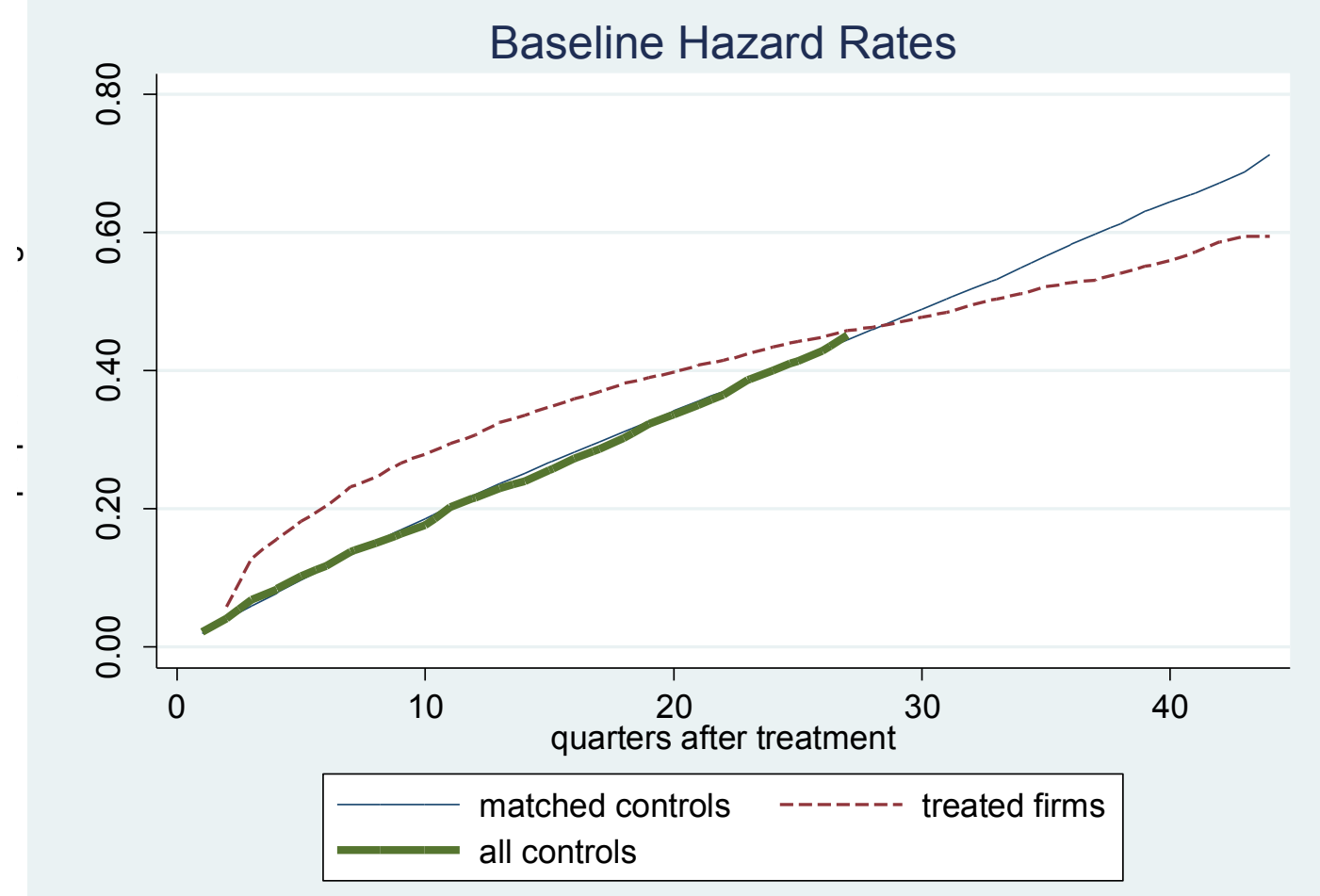


Figure 3.

The impact on exit hazard of employing udocumented workers,

over time since treatment (specification A with time varying treatement effect).

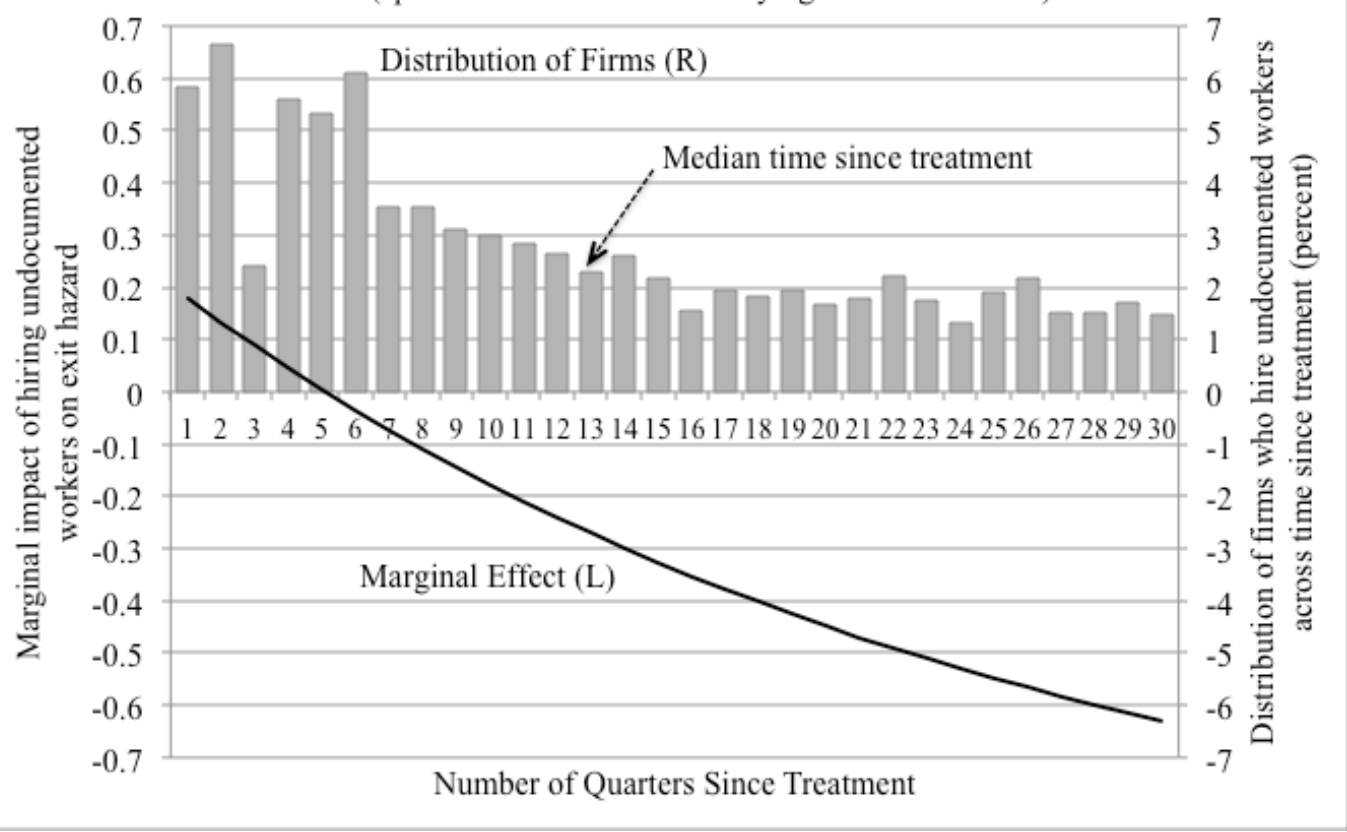

Note: The last quarter of data is 2006 Q4; not all firms are observed for a full 30 quarters.

Figure 4.

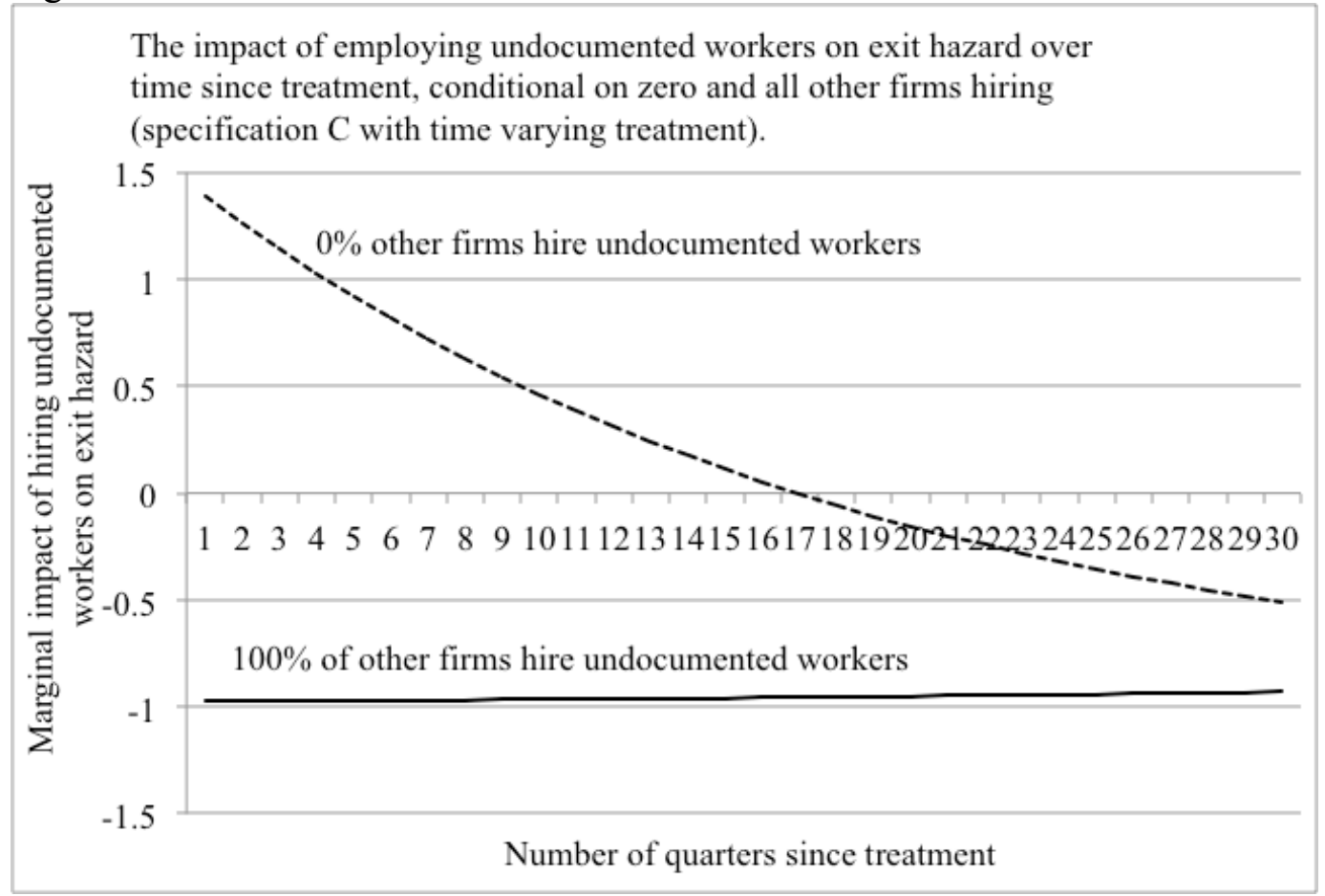

Note: The last quarter of data is 2006 Q4; not all firms are observed for a full 30 quarters. 
Figure 5.

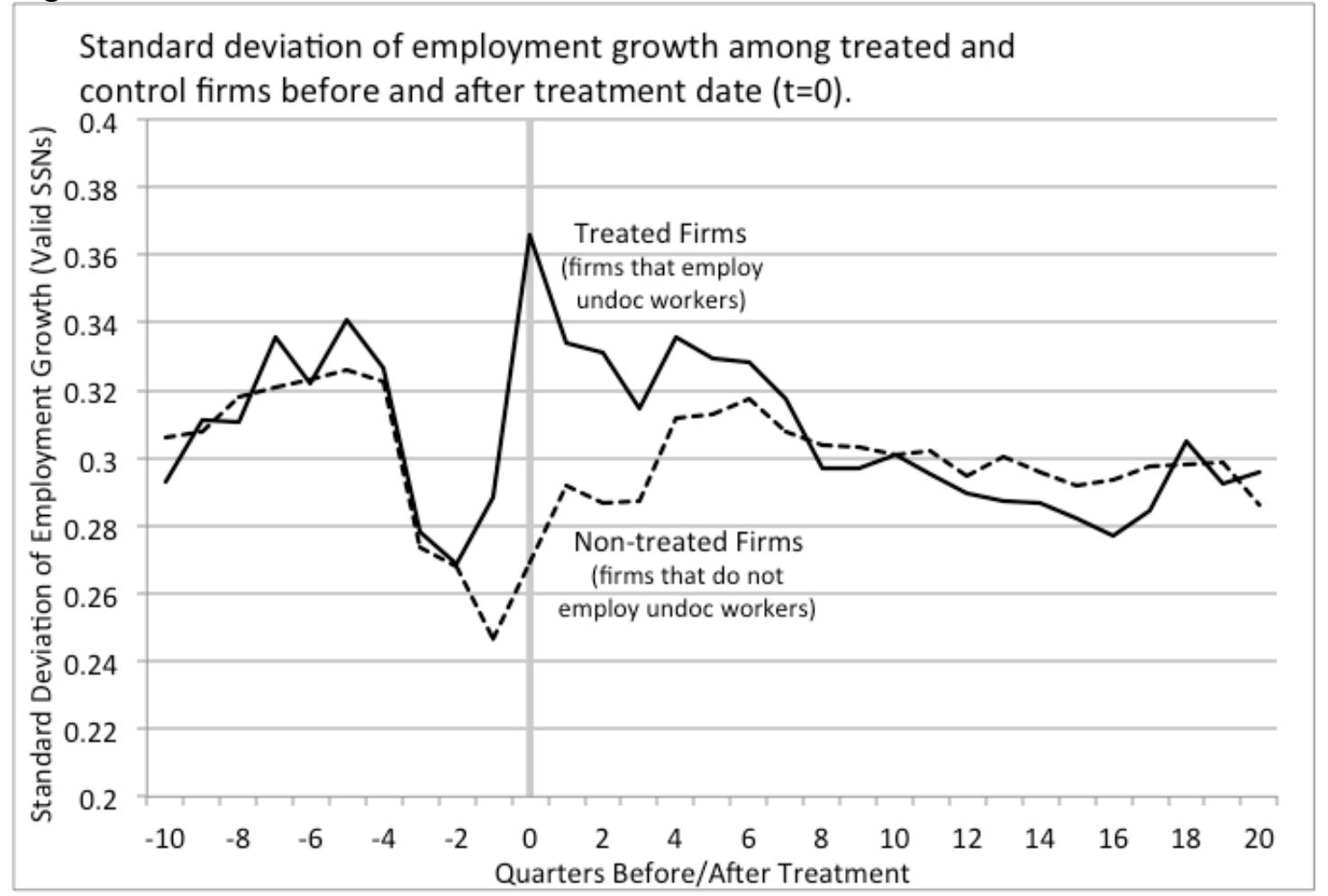

Note: The standard deviation of documented worker employment only is plotted to avoid confounding firm stability with the volatility of undocumented worker employment in general. 
Table 1. Select sample means.

\begin{tabular}{|c|c|c|}
\hline & $\begin{array}{c}\text { Firms that do not } \\
\text { employ } \\
\text { undocumented } \\
\text { workers }\end{array}$ & $\begin{array}{l}\text { Firm that do } \\
\text { employ } \\
\text { undocumented } \\
\text { workers }\end{array}$ \\
\hline $\begin{array}{l}\text { Ind } U N D O C \in[0,1] \\
\text { (share of firm's industry that employs undocumented workers) }\end{array}$ & $\begin{array}{c}0.042 \\
(0.058)\end{array}$ & $\begin{array}{c}0.098 \\
(0.090)\end{array}$ \\
\hline $\begin{array}{l}\text { BroadMarket } \in[0,1] \\
\text { (measure of employment concentration in firm's industry) }\end{array}$ & $\begin{array}{c}0.656 \\
(0.134)\end{array}$ & $\begin{array}{c}0.654 \\
(0.136)\end{array}$ \\
\hline $\begin{array}{l}\text { Higher Education } \in[0,1] \\
\text { (percent of workers in firm's 3-digit industry with college) }\end{array}$ & $\begin{array}{c}0.532 \\
(0.163)\end{array}$ & $\begin{array}{c}0.440 \\
(0.134)\end{array}$ \\
\hline $\begin{array}{l}\text { Labor Intensity } \in[0,1] \\
\text { (share of total wage bill in 3-digit industry output) }\end{array}$ & $\begin{array}{c}0.388 \\
(0.158)\end{array}$ & $\begin{array}{c}0.358 \\
(0.113)\end{array}$ \\
\hline Employment & $\begin{array}{c}11.581 \\
(51.632)\end{array}$ & $\begin{array}{c}25.444 \\
(78.200)\end{array}$ \\
\hline Wage (quarterly earnings) & $\begin{array}{l}\$ 8,223.09 \\
(9,362)\end{array}$ & $\begin{array}{l}\$ 6,037.01 \\
(4,713.82)\end{array}$ \\
\hline Proportion of Documented Workers Earning $<\mathrm{R} \$ 3,000 /$ quarter & $\begin{array}{c}0.323 \\
(0.287)\end{array}$ & $\begin{array}{c}0.397 \\
(0.262)\end{array}$ \\
\hline Firm Age (quarters, starting in 1990, Q1) & $\begin{array}{c}26.120 \\
(15.510)\end{array}$ & $\begin{array}{c}21.838 \\
(14.905)\end{array}$ \\
\hline Multi-establishment $=0,1$ & 0.011 & 0.026 \\
\hline Employment Churning & $\begin{array}{l}0.256 \\
(0.671)\end{array}$ & $\begin{array}{c}0.544 \\
(0.739)\end{array}$ \\
\hline Employee Tenure (quarters, starting in 1990, Q1) & $\begin{array}{c}7.001 \\
(4.711)\end{array}$ & $\begin{array}{c}4.828 \\
(3.548)\end{array}$ \\
\hline Employment Variability & $\begin{array}{l}178.116 \\
(53,612)\end{array}$ & $\begin{array}{l}319.490 \\
(11,171)\end{array}$ \\
\hline
\end{tabular}

Note: These are sample means and do not reflect treated and control groups created through the matching process. Standard deviations are in parentheses. Treated versus control group means are found in Table C7. Employment churning is constructed as the number of accessions plus separations minus the net employment change, all divided by average employment in the quarter, averaged over the period from the first quarter in the data set to four quarters ago. Employment variability is calculated as the variance in total employment levels from the first quarter in the data set to four quarters ago. 
Table 2. Cox Proportional Hazard regression results.

\begin{tabular}{|c|c|c|c|c|c|c|}
\hline \multirow[t]{2}{*}{ Specification: } & \multicolumn{2}{|c|}{ (A) } & \multicolumn{2}{|c|}{ (B) } & \multicolumn{2}{|c|}{ (C) } \\
\hline & Coef. & S.E. & Coef. & S.E. & Coef. & S.E. \\
\hline$U N D O C$ & $\begin{array}{l}-0.210 * * * \\
{[-0.1893]}\end{array}$ & 0.054 & & & $\begin{array}{l}0.447 \\
{[-0.0034]}\end{array}$ & 0.317 \\
\hline *Agriculture & & & $\begin{array}{c}0.362 \\
{[0.0163]}\end{array}$ & 0.304 & & \\
\hline *Construction & & & $\begin{array}{l}-0.009 \\
{[-0.0004]}\end{array}$ & 0.087 & & \\
\hline *Manufacturing & & & $\begin{array}{l}-0.100 \\
{[-0.0067]}\end{array}$ & 0.132 & & \\
\hline *Transport/Utilities & & & {$[-0.073 * * *$} & 0.247 & & \\
\hline *Wholesale Trade & & & $\begin{array}{c}0.279 \\
{[0.0156]}\end{array}$ & 0.185 & & \\
\hline *Retail Trade & & & $\begin{array}{c}0.129 \\
{[0.0066]}\end{array}$ & 0.127 & & \\
\hline *Financial Services & & & $\begin{array}{c}0.380 * \\
{[0.0560]}\end{array}$ & 0.213 & & \\
\hline *Information & & & $\begin{array}{l}1.188 * * * \\
{[0.1797]}\end{array}$ & 0.385 & & \\
\hline *Prof./Business Srves & & & $\begin{array}{l}-0.674 * * * \\
{[-0.0320]}\end{array}$ & 0.118 & & \\
\hline *Education/Health & & & $\begin{array}{l}3.900 * * * \\
{[0.0941]}\end{array}$ & 0.238 & & \\
\hline *Leisure/Hospitality & & & $\begin{array}{l}-1.073 * * * \\
{[-0.0628]}\end{array}$ & 0.118 & & \\
\hline *Other Services & & & $\begin{array}{l}-0.891 * * * \\
{[-0.0568]}\end{array}$ & 0.142 & & \\
\hline IndUNDOC & 0.132 & 0.300 & 0.178 & 0.281 & $1.694 * * *$ & 0.348 \\
\hline$U N D O C^{*} I n d U N D O C$ & & & & & $\begin{array}{l}-3.706^{* * *} \\
{[-0.0364]^{b}}\end{array}$ & 0.500 \\
\hline BroadMarket & $1.091 * * *$ & 0.220 & $0.917 * * *$ & 0.220 & $1.705^{* * *}$ & 0.278 \\
\hline UNDOC ${ }^{*}$ BroadMarket & & & & & $\begin{array}{l}-1.488 * * * \\
{[-0.1166]^{\mathrm{a}}}\end{array}$ & 0.407 \\
\hline Higher Education & $-1.880 * * *$ & 0.322 & $-1.934 * * *$ & 0.285 & $-4.188 * * *$ & 0.328 \\
\hline UNDOC ${ }^{*}$ HighEd & & & & & $\begin{array}{c}4.519 * * * \\
{[0.0462]^{\mathrm{b}}}\end{array}$ & 0.426 \\
\hline Labor Intensity & $1.571 * * *$ & 0.202 & $1.742 * * *$ & 0.188 & $3.155 * * *$ & 0.276 \\
\hline UNDOC* LaborInt & & & & & $\begin{array}{l}-2.645^{* * *} \\
{[-0.0261]^{b}}\end{array}$ & 0.350 \\
\hline Employment Churning & 0.007 & 0.018 & 0.007 & 0.022 & 0.018 & 0.069 \\
\hline UNDOC*Churning & & & & & $\begin{array}{l}-0.342 * * * \\
{[-0.2859]^{\mathrm{a}}}\end{array}$ & 0.079 \\
\hline Log Employment & $-0.921 * * *$ & 0.060 & $-0.926 * * *$ & 0.058 & $-0.887 * * *$ & 0.056 \\
\hline
\end{tabular}




\begin{tabular}{|l|l|l|l|l|l|l|}
\hline Log Employment Sq. & -0.026 & 0.017 & $-0.028^{*}$ & 0.016 & $-0.030 * *$ & 0.015 \\
\hline Log Wage & $-0.067 * * *$ & 0.011 & $-0.059 * * *$ & 0.011 & $-0.062 * * *$ & 0.012 \\
\hline Log Wage Sq. & $0.001 * * *$ & 0.0002 & $0.001 * * *$ & 0.0002 & $0.001 * * *$ & 0.0002 \\
\hline Part-Time Empl. & $0.795^{* * *}$ & 0.121 & $0.865 * * *$ & 0.124 & $0.911^{* * *}$ & 0.138 \\
\hline Firm Age & $0.031 * * *$ & 0.010 & $0.030^{* * *}$ & 0.010 & $0.035^{* * *}$ & 0.010 \\
\hline Firm Age Sq. & $-0.001 * * *$ & 0.0002 & $-0.001 * * *$ & 0.0002 & $-0.001 * * *$ & 0.0002 \\
\hline Multi-establishment & 0.192 & 0.275 & 0.298 & 0.263 & 0.313 & 0.252 \\
\hline Log Employee Tenure & $-0.544 * * *$ & 0.085 & $-0.520^{* * *}$ & 0.081 & $-0.649 * * *$ & 0.093 \\
\hline Log Empl. Variability & $0.412^{* * *}$ & 0.037 & $0.411 * * *$ & 0.040 & $0.404 * * *$ & 0.040 \\
\hline Log Industry Growth & -0.190 & 0.188 & -0.168 & 0.195 & -0.207 & 0.180 \\
\hline County-sector Growth & -0.046 & 0.116 & -0.063 & 0.115 & -0.029 & 0.106 \\
\hline County Pop Growth & $-3.418^{* * *}$ & 1.137 & $-3.629 * * *$ & 1.203 & $-3.075 * * *$ & 1.089 \\
\hline Log per capita Income & $1.237 * * *$ & 0.133 & $1.263 * * *$ & 0.114 & $1.198^{* * *}$ & 0.133 \\
\hline Hispanic Enrollment & $1.934 * * *$ & 0.502 & $2.004 * * *$ & 0.457 & $1.887 * * *$ & 0.494 \\
\hline Log Pop Density & $-0.144 * * *$ & 0.024 & $-0.147 * * *$ & 0.025 & $-0.138^{* * *}$ & 0.025 \\
\hline
\end{tabular}

Notes: Sector effects are also included. $U N D O C=1$ if a firm employs undocumented workers and is zero otherwise. The standard errors are bootstrapped using 200 repetitions. $*=$ significant at the 10 percent level, $* *=$ significant at the 5 percent level, and $* * *=$ significant at the 1 percent level. Number of observations is 365,497 . Average baseline hazard across firms, across time is 0.289 . Marginal effects are in brackets ( ${ }^{\mathrm{a}}$ corresponds to the effect of a one percentage point change in the regressor, ${ }^{b}$ corresponds to the effect of a one standard deviation change in the regressor.) BroadMarket is based on a modified Duncan index of dissimilarity (Duncan and Duncan 1955):

$D_{i}=\frac{1}{2} \sum_{c=1}^{N_{c}}\left|\frac{e_{i c}}{E_{i}}-\frac{1}{N_{c}}\right|$, where $N_{c}$ is the number of counties (159), $e_{i c}$ is the number of workers in industry $i$ that are in county $c, E_{i}$ is the total employment in industry $i, 1 / N_{c}$ is the share of workers that would need to be employed in each county for there to be an equal distribution of workers in the industry across counties. The closer $D_{i}$ gets to 0 (more equally distributed workers), the more diversified the industry and the more local the market.

The closer $\mathrm{D}$ gets to 1 , the more concentrated is employment in that industry and thus serving a broader market. 


\section{Appendix A: Using SSNs to Identify Undocumented Workers}

\section{A.1. Identifying Invalid Social Security Numbers}

Every quarter employers must file a report with their state's Department of Labor detailing all wages paid to workers who are covered under the Social Security Act of 1935. Each worker on this report is identified by his/her social security number (SSN). There are a number of ways in which one can establish that a reported social security number is invalid. The Social Security Administration provides a service by which an employer can upload a file of SSNs for checking, but one must register as an employer to obtain this service. ${ }^{1}$ In addition, there are several known limitations on what can be considered a valid social security number, so a simple algorithm is used to check whether each number conforms to the valid parameters.

There are three pieces to a SSN. ${ }^{2}$ The first three numbers are referred to as the Area Number. This number is assigned based on the state in which the application for a SSN was made; it does not necessarily reflect the state of residence. The lowest Area Number possible is 001 and the highest Area Number ever issued, as of December 2006, is 772. Using information provided by the SSA, the dates at which area numbers between 691 and 772 are first assigned can be determined. Any SSN with an Area Number equal to 000, greater than 772, or which shows up before the officially assigned date, will be considered invalid.

The second piece of a SSN consists of the two-digit Group Number. The lowest group number is 01 , and they are assigned in non-consecutive order. Any SSN with a Group Number equal to 00 or with a Group Number that appears in the data out of sequence with the Area Number will be considered invalid.

\footnotetext{
${ }^{1}$ See Social Security Number Verification Service $<$ http://www.ssa.gov/employer/ssnv.htm>.

${ }^{2}$ Historical information and information about valid SSNs can be found at the Social Security Administration's web sites: <http://www.ssa.gov/history/ssn/geocard.html>, <http://www.xocialsecurity.gov/employer/stateweb.htm>, and $<$ http://www.socialsecurity.gov/employer/ssnvhighgroup.htm $>$.
} 
The last four digits of a SSN are referred to as the Serial Number. These are assigned consecutively from 0001 to 9999 . Any SSN with a Serial Number equal to 0000 is invalid.

In 1996 the Internal Revenue Service (IRS) introduced the Individual Tax Identification Number (ITIN) to allow individuals who had income from the U.S. to file a tax return (the first ITIN was issued in 1997). It is simply a "tax processing number," and does not authorize an individual to work in the U.S. Employers are instructed by the IRS to "not accept an ITIN in place of a SSN for employee identification for work. An ITIN is only available to resident and nonresident aliens who are not eligible for U.S. employment and need identification for other tax purposes." ITIN numbers have a "9" in the first digit of the Area Number and a "7" or "8" in the first digit of the Group Number. Anyone with this numbering scheme will be identified as having an invalid Area Number; the percent of SSNs with high area numbers that also match the ITIN numbering scheme has risen from about one percent in 1997 to over 60 percent by the end of 2006 .

A series of SSNs were de-commissioned by the Social Security Administration because they had been put on fake Social Security Cards used as props to sell wallets. ${ }^{4}$ Apparently, some people who purchased the wallets thought the fake Social Security Cards were real and started using them as their own. If any of these 21 "pocketbook" SSNs appear in the data, they are considered invalid, although their frequency is so low as to be inconsequential. In addition, a number of SSNs are exactly equal to the employer identification number. These are invalid, primarily because they have too few digits. In any instance where a SSN is used for more than one person on a firm's UI wage report or does not have the required number of digits (including zeros), the SSN is considered invalid.

\footnotetext{
3 "Hiring Employees," <http://www.irs.gov/businesses/small/article/0,id=98164,00.html>. Also see, "Individual Taxpayer Identification Number (ITIN)," <http://www.irs.gov/individuals/article/0,,id=96287,00.html>.

${ }^{4}$ See U.S. Department of Housing and Urban Development (1990).
} 
The possibility that someone fraudulently uses a valid SSN assigned to someone else poses a special problem. First of all, the SSN will show up multiple times across firms in one quarter for workers with different surnames (the wage report includes the first three characters of the workers' surnames). With this information alone, it is not possible to know which worker is using the SSN fraudulently and who the valid owner of the number is. If one of the $\mathrm{SSN} /$ surname pairs shows up in the data initially in a quarter by itself, this is the pair that is considered valid and all other duplicates (with different surnames) are considered invalid.

\section{A.2. Does "Invalid" mean "Undocumented?"}

Not all invalid SSN are classified as undocumented workers; examining the patterns of incidence of different types of invalid SSNs suggests that some types are firm generated rather than worker generated. Figure A1 illustrates the incidence patterns across types of invalid SSNs in construction. The percent of workers with SSNs having a high area number or out-ofsequence group number displays the expected growth in undocumented workers (see Hoefer et al. 2007), whereas the incidence of SSNs for other reasons exhibits a flat to declining, highly seasonal pattern (this seasonality appears in all other sectors, as well). The strong seasonal nature of the other invalid reasons suggests that firms are temporarily assigning invalid SSN numbers to workers before having time to gather the information for the purpose of record keeping/reporting. Or, firms may decide to not bother obtaining a SSN for workers who will only be employed a very short time. ${ }^{5}$ The high degree of churning observed among workers with invalid SSNs for these other reasons is consistent with either of these practices.

[Figure A1 here]

\footnotetext{
${ }^{5}$ Indeed, a worker has 90 days to resolve a discrepancy that results in the receipt of a "no-match" letter from the Social Security Administration. The employee may be long gone before such a letter is even received.
} 
Since there is no way to know whether a temporary assignment by the firm of an invalid $\mathrm{SSN}$ is to merely cover for temporary employment of an undocumented worker or to allow the firm to file its wage report before having had a chance to record the worker's valid SSN, the analysis below takes the conservative tack by considering as undocumented only those workers whose SSNs are classified as invalid because the area number is too high or the group number is assigned out of sequence; workers with invalid SSNs for any other reason are considered neither undocumented nor documented and, thus, are excluded from the analysis. This will clearly undercount the actual number of undocumented workers. However, all workers, regardless of SSN classification, are included in counts of aggregate firm employment.

Figure 1 in the text plots the prevalence of undocumented workers in the seven broadly defined sectors with the highest incidences. The concentration of workers in these sectors has also been identified nationally by Fortuny et al. (2007). ${ }^{6}$ The pattern of growth is also consistent with Fortuny et al. who estimate that 72 percent of unauthorized immigrants in Georgia arrived in the last 10 years. Figure A2, showing the share of firms employing undocumented workers, reflects the same pattern of growth.

[Figure A2 here]

\section{A.3. Are Undocumented Workers Correctly Identified?}

There are several reasons we are confident that the sample of undocumented workers is representative. First of all, the rate of growth seen in both the number and percent of undocumented workers identified in Georgia matches closely the rate of growth in the Social Security Administration's (SSA) earnings suspense file (ESF). The ESF is a repository of social security taxes paid by employers that cannot be matched to a valid name or SSN. It is widely

\footnotetext{
${ }^{6}$ Fortuny et al. (2007) estimate that nationally in 2004 the percent of workers in leisure and hospitality and construction that was undocumented was 10 percent each, nine percent of workers in agriculture, and six percent each in manufacturing, professional and business services, and other services. Also see Pena (2009).
} 
believed that this growth in the ESF reflects growing incidence of unauthorized work in the U.S. (Bovbjerg 2006).

Figure A3 plots the number of workers (panel a) and the percent of workers (panel b) identified as undocumented along with the size of the ESF. This figure shows a remarkable consistency between the growth seen in workers identified as undocumented and the ESF.

\section{[Figure A3 here]}

As mentioned in the text, data suggest that between 40 and 60 percent of Mexicans in the U.S. are undocumented, and that 61 percent of unauthorized immigrants come from Mexico. Clearly not all Hispanics are undocumented, or vice versa. However using weighted data from the Current Population Survey (CPS), we calculate the average annual growth in total workers and total number of foreign born, Hispanic workers in the U.S. and in Georgia in order to compare growth rates to those in our sample. These results are reported in Table A1. The work force in GA grew faster over the period than the U.S. work force (2.9 percent vs. 1.5 percent, respectively). In addition, the number of foreign born, Hispanic workers in the U.S. grew faster (eight percent per year) than the overall work force; this phenomenon has been documented by others (Passel and Cohn 2009). But most importantly for our purposes is that the growth rate of foreign born, Hispanic workers in GA (roughly 27 percent per year), which is much larger than in the U.S. overall (also see Passel and Cohn 2009), is similar to the growth in the number of workers in GA classified here as undocumented. We also observe a similarly large growth rate in the number of foreign born, Hispanic workers with less than a high school degree (21\%), among which we might expect a larger share of undocumented workers than among foreign born Hispanics in general.

[Table A1 here] 
The close match in growth rates in the number of workers classified as undocumented with that of the SSA ESF and with the number of foreign born, Hispanic workers in Georgia as measured by the CPS, suggests that the mechanism employed in this paper to identify undocumented workers is accurate; it's clear that not all undocumented workers are being captured in the data, but likely those identified as undocumented are undocumented. Any remaining miss-classifications will show up in the error term and limit the estimation in its ability to identify any systematic relationships between wages and characteristics of documented workers and their employers. However, in spite of our confidence that we are correctly identifying undocumented workers in the state of Georgia, it must be stressed that this sample of undocumented workers may or may not be representative of the average undocumented worker in the state. Without an independent source of characteristics of undocumented workers in the state of Georgia, there is no way to establish that.

Note that it is not essential for an employer to be able to distinguish between valid and invalid SSNs in order to practice monopsonistic discrimination. All that is necessary is that the employer can use some identifying characteristic(s) to distinguish between groups of workers. In this case, ethnic Hispanic characteristics and limited English skills are features that employers use to identify (within a certain degree of accuracy) which workers are likely undocumented. Furthermore, it is likely that the workers identified as undocumented within a particular firm represent merely the tip of the iceberg of that firm's hiring behavior regarding undocumented workers. In other words, it is probably more likely that the undocumented workers identified at any firm represent only a share of that firm's hiring than it is that there are a large number of firms employing undocumented workers and not including any of them on UI reports. From anecdotal evidence gleaned from an unscientific survey of employers, firms are most afraid of 
being caught not paying their appropriate taxes than they are in getting caught employing undocumented workers. This suggests that if a firm employs undocumented workers on a regular basis, they will make some effort to report them -- perhaps not all of them, but at least those employed on a longer term basis (the tip).

Figure A1.

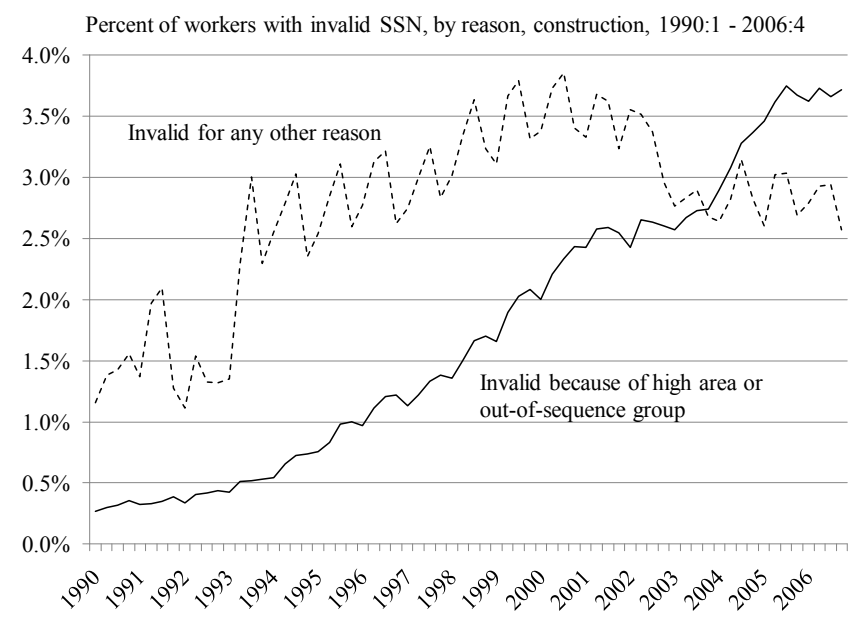

Figure A2.

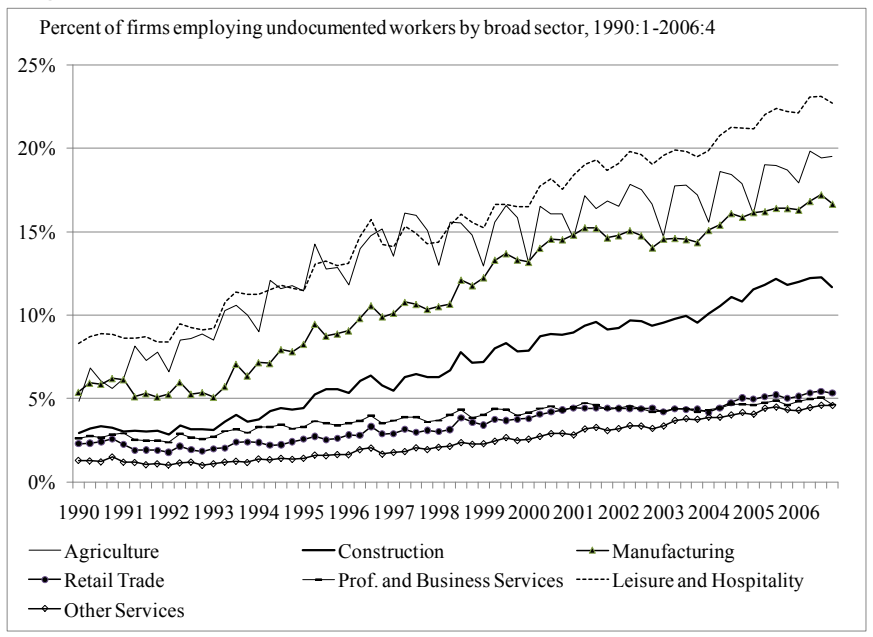

Figure A3. Growth in the earnings suspense file and the total number and percent of workers identified as undocumented in Georgia, 1990-2006.
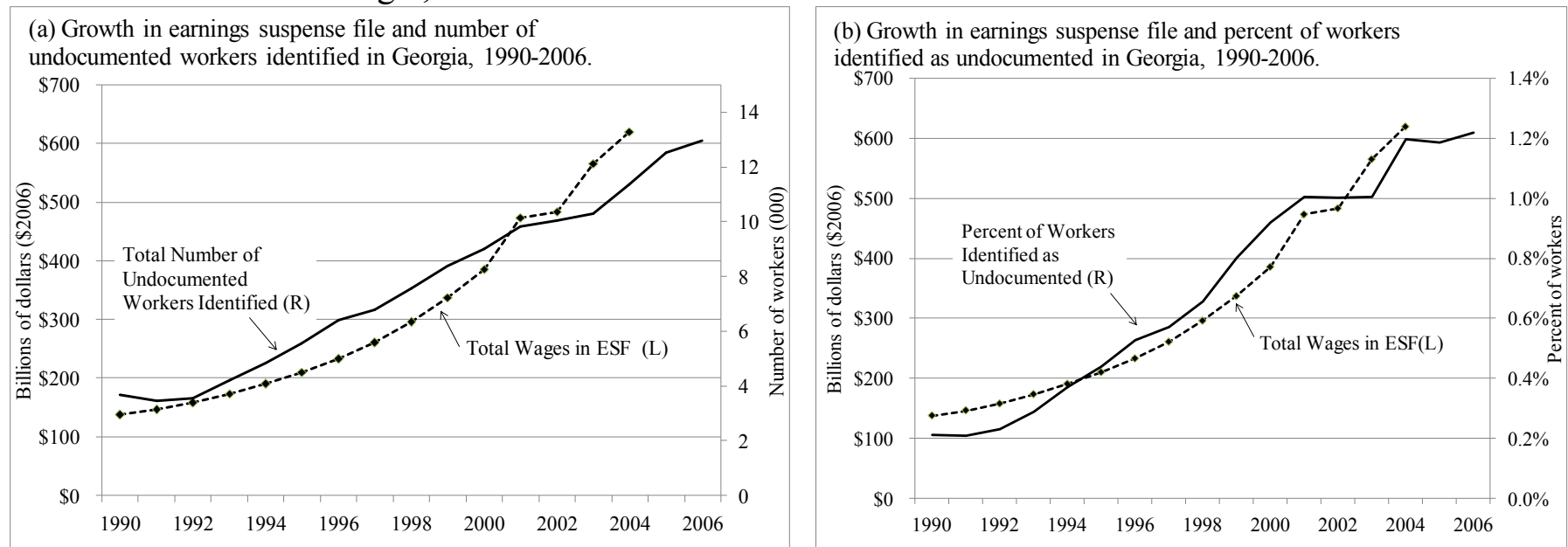

Source: Huse (2002) for estimates 1990-2000, Johnson (2007) for estimates 2001-2004, and authors' calculations. Dollar estimates reflect 2006 values, using the PCE chain-weighted deflator. 
Table A1. Average annual growth, 1994-2006, in US and GA employment, Hispanic workers, and workers identified as undocumented.

Average Annual Growth Rate of:

Total number of workers in the U.S.

$1.48 \%$

Total number of foreign born, Hispanic workers in the U.S. $\quad 8.03 \%$

Total number of foreign born, Hispanic workers with less $\quad 7.28 \%$

than a high school degree in U.S.

Total number of workers in Georgia

$2.92 \%$

Total number of foreign born, Hispanic workers in Georgia $\quad 26.82 \%$

Total number of foreign born, Hispanic workers with less $\quad 21.48 \%$

than a high school degree in Georgia

Total number of workers in GA identified as undocumented $\quad 25.29 \%$

Source: Current Population Survey, Basic Survey (March), 1994-2006; and authors' calculations.

Note: 1994 is used as starting year, since it is the first year the Current Population Survey has a reliable indicator of Hispanic ethnicity. 


\section{Appendix B: Matching Process}

The matching procedure has four steps. The first is to define more precisely how to define whether a firm systematically employs undocumented workers. Second, we impose some exact criteria within which we will consider possible matches. Third, we estimate probability of employment undocumented workers. Last, we select matches within a propensity score bandwidth surrounding the employing firm's propensity score. In this context, employment of undocumented workers can be thought of as a "treatment" on a firm's performance.

Identification of a firm as one that employs undocumented workers is not a trivial matter; we distinguish treated and non-treated firms in the following way. A firm is considered an undocumented worker employer in a quarter if it has at least one worker-generated invalid SSN on its payroll during the quarter. We identify the first quarter when this occurs for a firm as the treatment quarter and count the number of quarters it exists from the data from that point on. A firm that is an undocumented worker employer in at least 50 percent of these quarters and begins employing undocumented workers after 1990 but before 2006 is considered a treated firm. Firms that are undocumented worker employers in 20 percent or fewer of these quarters are in the non-treatment group. Firms that are undocumented worker employers in over 20 percent but less than 50 percent of these quarters or begin employing undocumented workers in 1990 or 2006 are excluded from the analysis. A robustness test, described and detailed in Appendix D, is performed to investigate the sensitivity of the results to this definition of treatment.

The more often a firm has worker-generated invalid SSNs on its payroll, the more confident we are that the SSNs are not invalid due to clerical error. Also, the more consistently a firm employs undocumented workers, the more likely this practice will have an effect on the firm's survivability. We thus impose the 50 percent and 20 percent cut-offs to compare firms 
consistently having invalid, worker-generated SSNs to ones having them infrequently or never. We are unable to observe the pre-treatment characteristics of firms employing undocumented workers in 1990, so we cannot conduct our matching procedure on them. We drop firms first employing undocumented workers in 2006, because we would like to observe whether firms consistently employ undocumented workers or not and whether they survive or die several quarters later.

We impose some exact criteria on which firms in the non-treated group can be in the matched comparison group. We require exact matches on 6-digit NAICS industry and on year and quarter (the treated firm's treatment quarter). Non-treated firms that do not meet these criteria for matching with any treated firms are dropped from the analysis at this point.

We then estimate equations for the probability of treatment using these restricted samples, separately for each broad sector. In order to address potential concerns of endogeneity, we employ a variety of lag structures, depending on the regressor; this is detailed below. Nontreated firms appear in the regression once for each potential match with a treated firm, and the regressors for that observation are also measured four quarters prior to the potentially matched treated firm's treatment quarter.

We impose a common support and a 0.9-1.1 bandwidth of the treated to non-treated propensity score ratio. Epanechnikov kernel weights are assigned to control firms within the bandwidth. The sampling is done with replacement, so if there is a non-treated firm with a propensity score within the bandwidth of $x$ treated firms, this firm will be included as a control firm $x$ times. $^{24}$

\footnotetext{
${ }^{24}$ Each set of non-treated firm values in the probit and hazard regressions is specific to the treated firm to which it is matched.
} 


\section{B.1. First-stage UNDOC Probit Results}

In order to find a good control "match" for each firm that employs undocumented workers, a probit analysis is performed to determine each firm's propensity to employ undocumented workers. Using the coefficient estimates from this estimation, each firm will be assigned a probability of "treatment," or propensity to become a firm that consistently employs undocumented workers. These estimations were performed separately by broad sector and the results are reported in Tables B1-B4. Table B5 tells us that there are sufficient numbers of treated and matched control firms in each quintile to produce reliable estimates. The distribution of treated firms across broad sectors is compared with the distribution of controls across sectors in Table B6. The regressors are described in the text.

[Tables B1-B4, B5, and B6 here]

\section{B.2. Matching Balancing Tests}

Table B7 reports kernel-weighted means of the independent variables in the probits (except log employment squared, wage squared, and three-digit industry and year-quarter dummies) for the matched comparison and treated groups, the Rosenbaum and Rubin (1985) test of standardized differences, and a $t$ test for the difference in kernel-weighted means. Note that potential controls are limited to ones with exact matches on six-digit industry and year-quarter, so balance on these variables is already assured. We also run kernel-weighted regressions of the probit independent variables on a quartic of propensity scores and a quartic of propensity scores interacted with treatment dummies and show $F$ tests for the joint significance of the interaction terms in the table. This test was performed in Smith and Todd (2005).

[Table B7 here] 
The independent variable means for each propensity score quintile are shown in Table B8. The differences between treated and control firms are small in each quintile. B9 shows Hotelling $T^{2}$ tests of the joint null of equal means of all the probit independent variables included in Table B7, separately by propensity score quintile.

[Table B8 and B9 here]

The $t$ test, $F$ test, and Hotelling $T^{2}$ test values are statistically significant in most cases, suggesting some differences between the treated firms and matched controls prior to treatment. We have also conducted the $t$ and $F$ tests on the treated firms and non-treated firms after restricting the non-treated firm sample to those that are potential matches, but before imposing the 0.9-1.1 propensity score bandwidth and kernel weighting. With the exception of countysector growth, the $t$ and $F$ test values are larger than those shown in Table B7 by orders of magnitude. And the matching and reweighting reduces the standardized differences by over 80 percent in most cases. The usual rule of thumb in the matching literature is that standardized difference values above 20 in absolute value are large (see Rosenbaum and Rubin 1985) - none of the values here are anywhere near that big. In sum, though some differences remain, the matching procedure has improved the balance of the samples considerably. 
Table B1. First-stage UNDOC probit results; Agriculture, Construction, and Manufacturing.

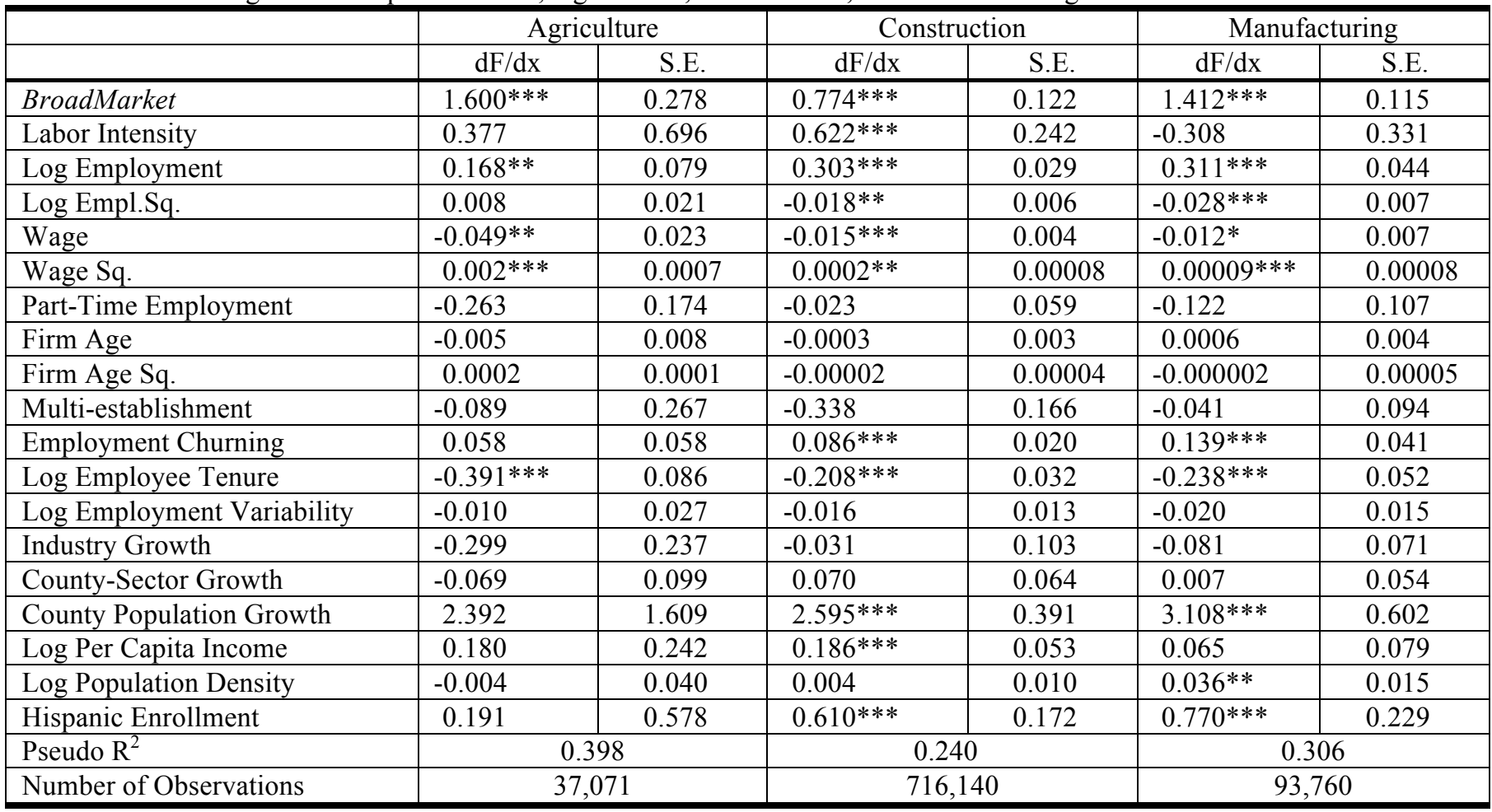

Notes: Year-quarter and three digit NAICS industry effects are also included. These are robust standard errors. * $=$ significant at the 10 percent level, $* *=$ significant at the 5 percent level, and $* * *=$ significant at the 1 percent level.

Table B2. First-stage UNDOC probit results; Transp. \& Utilities, Wholesale Trd, and Retail Trd.

\begin{tabular}{|c|c|c|c|c|c|c|}
\hline & \multicolumn{2}{|c|}{ Transport \& Utilities } & \multicolumn{2}{|c|}{ Wholesale Trade } & \multicolumn{2}{|c|}{ Retail Trade } \\
\hline & $\mathrm{dF} / \mathrm{dx}$ & S.E. & $\mathrm{dF} / \mathrm{dx}$ & S.E. & $\mathrm{dF} / \mathrm{dx}$ & S.E. \\
\hline BroadMarket & $0.830 * * *$ & 0.263 & $0.486 * * *$ & 0.160 & $0.758 * * *$ & 0.126 \\
\hline Labor Intensity & 0.583 & 1.780 & & & & \\
\hline Log Employment & $0.110^{*}$ & 0.061 & $0.314 * * *$ & 0.036 & $0.138 * * *$ & 0.031 \\
\hline Log Employment Sq. & -0.003 & 0.010 & $-0.021 * *$ & 0.010 & -0.007 & 0.007 \\
\hline Log Wage & $0.038 *$ & 0.021 & $-0.031 * * *$ & 0.005 & $0.070 * * *$ & 0.020 \\
\hline Log Wage Sq. & -0.001 & 0.0006 & 0.0002 & 0.00006 & $-0.005 * * *$ & 0.001 \\
\hline Part-Time Employment & $0.508 * * *$ & 0.178 & $-0.249 * * *$ & 0.098 & 0.038 & 0.090 \\
\hline Firm Age & 0.004 & 0.006 & 0.003 & 0.005 & 0.0009 & 0.003 \\
\hline Firm Age Sq. & -0.00006 & 0.00008 & -0.00008 & 0.00006 & -0.00003 & 0.00005 \\
\hline Multi-establishment & -0.195 & 0.165 & 0.039 & 0.092 & -0.099 & 0.067 \\
\hline Employment Churning & -0.003 & 0.002 & $0.201 * * *$ & 0.045 & $0.098 * * *$ & 0.025 \\
\hline Log Employee Tenure & $-0.371 * * *$ & 0.064 & $-0.184 * * *$ & 0.053 & $-0.207 * * *$ & 0.039 \\
\hline Log Empl. Variability & 0.036 & 0.029 & -0.027 & 0.021 & 0.012 & 0.017 \\
\hline Industry Growth & 0.219 & 0.208 & 0.052 & 0.123 & 0.133 & 0.144 \\
\hline County-Sector Growth & -0.010 & 0.074 & 0.016 & 0.076 & -0.014 & 0.059 \\
\hline County Population Growth & $2.287 * *$ & 1.150 & $1.949 * * *$ & 0.739 & 0.252 & 0.646 \\
\hline Log Per Capita Income & 0.031 & 0.113 & 0.080 & 0.080 & $0.196 * * *$ & 0.067 \\
\hline Log Population Density & 0.007 & 0.024 & -0.014 & 0.016 & $0.024 *$ & 0.013 \\
\hline Hispanic Enrollment & 0.180 & 0.423 & $1.011 * * *$ & 0.263 & $0.758 * * *$ & 0.210 \\
\hline Pseudo $\mathrm{R}^{2}$ & \multicolumn{2}{|c|}{0.306} & \multicolumn{2}{|c|}{0.370} & \multicolumn{2}{|c|}{0.196} \\
\hline Number of Observations & \multicolumn{2}{|c|}{94,554} & \multicolumn{2}{|c|}{347,601} & \multicolumn{2}{|c|}{515,717} \\
\hline
\end{tabular}

See notes to Table B1. 
Table B3. First-stage UNDOC probit results; Financial Srvcs, Information, and Prof. \& Bus. Srves.

\begin{tabular}{|c|c|c|c|c|c|c|}
\hline & \multicolumn{2}{|c|}{ Financial Services } & \multicolumn{2}{|c|}{ Information } & \multicolumn{2}{|c|}{ Prof. \& Business Srves } \\
\hline & $\mathrm{dF} / \mathrm{dx}$ & S.E. & $\mathrm{dF} / \mathrm{dx}$ & S.E. & $\mathrm{dF} / \mathrm{dx}$ & S.E. \\
\hline BroadMarket & 0.211 & 0.205 & 0.302 & 0.335 & -0.036 & 0.141 \\
\hline Labor Intensity & $-2.422 * * *$ & 1.238 & -1.211 & 0.900 & $-0.593 * * *$ & 0.103 \\
\hline Log Employment & $0.215 * * *$ & 0.050 & $0.310 * * *$ & 0.057 & $0.199 * * *$ & 0.024 \\
\hline Log Employment Sq. & -0.006 & 0.011 & -0.013 & 0.010 & -0.019 & 0.005 \\
\hline Log Wage & -0.007 & 0.011 & $-0.035 * * *$ & 0.010 & $-0.014 * * *$ & 0.003 \\
\hline Firm Age & 0.0004 & 0.005 & 0.004 & 0.010 & -0.002 & 0.003 \\
\hline Firm Age Sq. & -0.00001 & 0.00008 & -0.0002 & 0.0001 & -0.000001 & 0.00004 \\
\hline Multi-establishment & $-0.254 * *$ & 0.109 & -0.134 & 0.136 & $0.204 * *$ & 0.082 \\
\hline Employment Churning & $0.174 * * *$ & 0.055 & -0.047 & 0.069 & 0.009 & 0.009 \\
\hline Log Employee Tenure & $-0.129 * *$ & 0.055 & $-0.294 * * *$ & 0.097 & $-0.215 * * *$ & 0.033 \\
\hline County Population Growth & 0.149 & 1.112 & -0.480 & 1.803 & $3.563 * * *$ & 0.562 \\
\hline Log Per Capita Income & 0.137 & 0.097 & 0.045 & 0.161 & 0.060 & 0.060 \\
\hline Log Population Density & $0.044 * *$ & 0.021 & $0.109 * * *$ & 0.037 & $0.026^{*}$ & 0.014 \\
\hline Hispanic Enrollment & $0.786 * * *$ & 0.384 & -0.955 & 0.932 & -0.051 & 0.283 \\
\hline Pseudo $\mathrm{R}^{2}$ & \multicolumn{2}{|c|}{0.300} & \multicolumn{2}{|c|}{0.338} & \multicolumn{2}{|c|}{0.279} \\
\hline Number of Observations & \multicolumn{2}{|c|}{346,930} & \multicolumn{2}{|c|}{17,506} & \multicolumn{2}{|c|}{714,750} \\
\hline
\end{tabular}

See notes to Table B1

Table B4. First-stage UNDOC probit results; Ed. \& Health, Leisure \& Hospitality, and Other Srvcs.

\begin{tabular}{|c|c|c|c|c|c|c|}
\hline & \multicolumn{2}{|c|}{ Education \& Health } & \multicolumn{2}{|c|}{ Leisure \& Hospitality } & \multicolumn{2}{|c|}{ Other Services } \\
\hline & $\mathrm{dF} / \mathrm{dx}$ & S.E. & $\mathrm{dF} / \mathrm{dx}$ & S.E. & $\mathrm{dF} / \mathrm{dx}$ & S.E. \\
\hline BroadMarket & $1.151 * * *$ & 0.203 & 0.219 & 0.199 & $0.727 * * *$ & 0.216 \\
\hline Labor Intensity & $1.137 * * *$ & 0.389 & 1.530 & 1.093 & -0.587 & 0.402 \\
\hline Log Employment & $0.228 * * *$ & 0.042 & $0.084 * * *$ & 0.032 & $0.100 * *$ & 0.046 \\
\hline Log Employment Sq. & $-0.036 * * *$ & 0.009 & 0.011 & 0.008 & 0.009 & 0.014 \\
\hline Log Wage & -0.003 & 0.005 & 0.021 & 0.016 & 0.033 & 0.025 \\
\hline Log Wage Sq. & -0.00004 & 0.00006 & -0.0008 & 0.0006 & $-0.002 *$ & 0.001 \\
\hline Part-Time Employment & 0.071 & 0.096 & $-0.191 * *$ & 0.086 & -0.040 & 0.102 \\
\hline Firm Age & 0.0005 & 0.005 & $-0.012 * * *$ & 0.003 & $0.007 *$ & 0.004 \\
\hline Firm Age Sq. & -0.00005 & 0.00006 & 0.00007 & 0.00005 & $-0.00007 * *$ & 0.00006 \\
\hline Multi-establishment & 0.068 & 0.108 & $-0.161 *$ & 0.088 & -0.234 & 0.220 \\
\hline Employment Churning & $0.138 * * *$ & 0.047 & $0.033 *$ & 0.020 & $0.131 * * *$ & 0.032 \\
\hline Log Employee Tenure & $-0.118 * *$ & 0.060 & $-0.126 * * *$ & 0.036 & $-0.298 * * *$ & 0.040 \\
\hline Log Empl. Variability & $0.044 * *$ & 0.022 & 0.019 & 0.013 & 0.031 & 0.024 \\
\hline Industry Growth & -0.142 & 0.208 & -0.039 & 0.145 & $-0.770 * * *$ & 0.187 \\
\hline County-Sector Growth & -0.0005 & 0.115 & 0.078 & 0.051 & $-0.296 * * *$ & 0.117 \\
\hline County Population Growth & $1.447 *$ & 0.885 & $1.990 * * *$ & 0.583 & $2.433 * * *$ & 0.781 \\
\hline Log Per Capita Income & -0.106 & 0.085 & $0.244 * * *$ & 0.060 & $0.144 *$ & 0.078 \\
\hline Log Population Density & $0.071 * * *$ & 0.018 & $0.027 * * *$ & 0.012 & $0.059 * * *$ & 0.018 \\
\hline Hispanic Enrollment & $0.640 *$ & 0.341 & $0.497 * *$ & 0.223 & $0.520 * *$ & 0.255 \\
\hline Pseudo $\mathrm{R}^{2}$ & \multicolumn{2}{|c|}{0.272} & \multicolumn{2}{|c|}{0.202} & \multicolumn{2}{|c|}{0.320} \\
\hline Number of Observations & \multicolumn{2}{|c|}{482,341} & \multicolumn{2}{|c|}{362,827} & \multicolumn{2}{|c|}{562,005} \\
\hline
\end{tabular}

See notes to table B1. 
Table B5. Frequency distribution of treated and matched control firms by propensity score quintile.

\begin{tabular}{lcc}
\hline Quintile & Treated & Matched Controls \\
\hline First & 222 & 14,217 \\
Second & 716 & 58,415 \\
Third & 1,254 & 93,952 \\
Fourth & 1,926 & 123,690 \\
Fifth & 1,991 & 69,114 \\
Total & 6,109 & 365,497 \\
\hline
\end{tabular}

Table B6. Distribution of treated and control firms across broad sectors.

\begin{tabular}{lccc}
\hline Sector & Treated Firms & Control Firms & Total \\
\hline Agriculture & 115 & 1,216 & 1,331 \\
Construction & 1,364 & 54,344 & 55,708 \\
Manufacturing & 587 & 3,784 & 4,371 \\
Transport/Utilities & 157 & 3,251 & 3,408 \\
Wholesale Trade & 466 & 15,788 & 16,254 \\
Retail Trade & 658 & 28,660 & 29,318 \\
Financial Services & 258 & 14,990 & 15,239 \\
Information & 58 & 512 & 570 \\
Prof./Business Srvcs & 855 & 65,884 & 66,739 \\
Education/Health & 327 & 46,964 & 47,291 \\
Leisure/Hospitality & 826 & 89,003 & 89,829 \\
Other Services & 447 & 34,992 & 35,439 \\
\hline Total & 6,109 & 359,388 & 365,497 \\
\hline
\end{tabular}


Table B7. Kernel matching balancing tests.

\begin{tabular}{|c|c|c|c|c|c|c|c|c|}
\hline & $\begin{array}{r}\mathrm{M} \\
\text { Before }\end{array}$ & $\begin{array}{l}\text { ans } \\
\text { Iatching }\end{array}$ & $\begin{array}{r}\mathrm{M} \\
\text { After } \mathrm{N}\end{array}$ & ns & & & t-test & $\begin{array}{l}\text { Regression- } \\
\text { based tests }\end{array}$ \\
\hline & Treated & Control & Treated & Control & $\%$ bias & $\begin{array}{l}\% \text { bias } \\
\text { reduction }\end{array}$ & $\begin{array}{c}\text { t-stat } \\
\text { (p-value) }\end{array}$ & $\begin{array}{c}\text { F-stat } \\
\text { (p-value) }\end{array}$ \\
\hline BroadMarket & 0.646 & 0.657 & 0.643 & 0.643 & 0.00 & 100.00 & $\begin{array}{l}0.00 \\
(1.000)\end{array}$ & $\begin{array}{l}0.00 \\
(1.000)\end{array}$ \\
\hline Higher Education & 0.438 & 0.533 & 0.443 & 0.443 & 0.00 & 100.00 & $\begin{array}{c}0.00 \\
(1.000)\end{array}$ & $\begin{array}{c}0.00 \\
(1.000)\end{array}$ \\
\hline Labor Intensity & 0.362 & 0.388 & 0.360 & 0.360 & 0.00 & 100.00 & $\begin{array}{c}0.00 \\
(1.000)\end{array}$ & $\begin{array}{c}0.00 \\
(1.000)\end{array}$ \\
\hline Log Employment & 1.672 & 0.867 & 2.283 & 2.239 & 4.10 & 94.58 & $\begin{array}{l}11.08 \\
(0.000)\end{array}$ & $\begin{array}{r}122.82 \\
(0.000)\end{array}$ \\
\hline Log Wage & 4.854 & 4.977 & 6.340 & 6.228 & 3.43 & 8.90 & $\begin{array}{l}7.28 \\
(0.000)\end{array}$ & $\begin{array}{l}52.97 \\
(0.000)\end{array}$ \\
\hline Part-Time Employment & 0.427 & 0.419 & 0.376 & 0.384 & -2.54 & -1.65 & $\begin{array}{l}-9.20 \\
(0.000)\end{array}$ & $\begin{array}{l}84.58 \\
(0.000)\end{array}$ \\
\hline Firm Age & 19.698 & 28.160 & 24.421 & 25.580 & -6.93 & 85.67 & $\begin{array}{l}-21.65 \\
(0.000)\end{array}$ & $\begin{array}{l}468.61 \\
(0.000)\end{array}$ \\
\hline Multi-establishment & 0.019 & 0.010 & 0.017 & 0.018 & -1.15 & 86.45 & $\begin{array}{l}-3.06 \\
(0.002)\end{array}$ & $\begin{array}{c}9.35 \\
(0.002)\end{array}$ \\
\hline Employment Churning & 0.598 & 0.200 & 0.468 & 0.494 & -4.11 & 93.55 & $\begin{array}{l}-8.33 \\
(0.000)\end{array}$ & $\begin{array}{l}69.35 \\
(0.000)\end{array}$ \\
\hline Log Employee Tenure & 1.341 & 1.934 & 1.551 & 1.578 & -3.68 & 95.47 & $\begin{array}{c}-13.31 \\
(0.000)\end{array}$ & $\begin{array}{l}177.18 \\
(0.000)\end{array}$ \\
\hline Log Empl. Variability & 1.696 & 0.713 & 2.410 & 2.389 & 1.54 & 97.95 & $\begin{array}{c}3.31 \\
(0.001)\end{array}$ & $\begin{array}{l}10.96 \\
(0.001)\end{array}$ \\
\hline Industry Growth & 0.034 & 0.028 & 0.031 & 0.031 & 0.00 & 100.00 & $\begin{array}{l}0.00 \\
(1.000)\end{array}$ & $\begin{array}{l}0.00 \\
(1.000)\end{array}$ \\
\hline County-Sector Growth & 0.035 & 0.026 & 0.032 & 0.031 & 0.75 & 85.60 & $\begin{array}{c}2.32 \\
(0.020)\end{array}$ & $\begin{array}{l}5.38 \\
(0.020)\end{array}$ \\
\hline County Population Growth & 0.026 & 0.022 & 0.025 & 0.025 & -0.24 & 98.85 & $\begin{array}{l}-0.72 \\
(0.472)\end{array}$ & $\begin{array}{c}0.52 \\
(0.472)\end{array}$ \\
\hline
\end{tabular}




\begin{tabular}{|c|c|c|c|c|c|c|c|c|}
\hline Log Per Capita Income & 3.337 & 3.297 & 3.334 & 3.330 & 1.54 & 93.10 & $\begin{array}{c}4.74 \\
(0.000)\end{array}$ & $\begin{array}{l}22.45 \\
(0.000)\end{array}$ \\
\hline Log Population Density & -0.576 & -0.757 & -0.595 & -0.639 & 3.30 & 84.71 & $\begin{array}{l}10.40 \\
(0.000)\end{array}$ & $\begin{array}{c}108.18 \\
(0.000)\end{array}$ \\
\hline Hispanic Enrollment & 0.052 & 0.044 & 0.051 & 0.051 & 1.59 & 91.80 & $\begin{array}{c}4.49 \\
(0.000)\end{array}$ & $\begin{array}{l}20.15 \\
(0.000)\end{array}$ \\
\hline
\end{tabular}

Table B8. Kernel matching means by propensity score quintile.

\begin{tabular}{|c|c|c|c|c|c|c|c|c|c|c|}
\hline & \multicolumn{2}{|c|}{ Quintile 1 } & \multicolumn{2}{|c|}{ Quintile 2} & \multicolumn{2}{|c|}{ Quintile 3} & \multicolumn{2}{|c|}{ Quintile 4} & \multicolumn{2}{|c|}{ Quintile 5} \\
\hline & Treated & Control & Treated & Control & Treated & Control & Treated & Control & Treated & Control \\
\hline BroadMarket & 0.607 & 0.607 & 0.607 & 0.606 & 0.608 & 0.607 & 0.637 & 0.637 & 0.689 & 0.691 \\
\hline Higher Education & 0.497 & 0.499 & 0.466 & 0.465 & 0.446 & 0.446 & 0.435 & 0.433 & 0.436 & 0.438 \\
\hline Labor Intensity & 0.390 & 0.392 & 0.385 & 0.384 & 0.361 & 0.360 & 0.356 & 0.357 & 0.351 & 0.351 \\
\hline Log Employment & 0.729 & 0.843 & 1.464 & 1.490 & 1.976 & 1.930 & 2.350 & 2.311 & 2.878 & 2.799 \\
\hline Log Wage & 8.528 & 7.852 & 6.698 & 6.494 & 6.373 & 6.328 & 6.439 & 6.222 & 5.850 & 5.885 \\
\hline Part-Time Employment & 0.317 & 0.311 & 0.359 & 0.371 & 0.364 & 0.364 & 0.370 & 0.382 & 0.402 & 0.412 \\
\hline Firm Age & 35.716 & 35.319 & 32.116 & 31.399 & 29.070 & 28.396 & 23.718 & 24.366 & 18.147 & 21.757 \\
\hline Multi-establishment & 0.000 & 0.002 & 0.010 & 0.005 & 0.014 & 0.015 & 0.015 & 0.019 & 0.026 & 0.027 \\
\hline Employment Churning & 0.195 & 0.143 & 0.286 & 0.279 & 0.363 & 0.389 & 0.477 & 0.500 & 0.622 & 0.675 \\
\hline Log Employee Tenure & 2.205 & 2.279 & 1.959 & 1.928 & 1.758 & 1.738 & 1.518 & 1.513 & 1.234 & 1.334 \\
\hline Log Empl. Variability & 0.814 & 0.727 & 1.309 & 1.315 & 1.819 & 1.845 & 2.414 & 2.432 & 3.351 & 3.282 \\
\hline Industry Growth & 0.018 & 0.017 & 0.023 & 0.021 & 0.030 & 0.030 & 0.035 & 0.034 & 0.032 & 0.034 \\
\hline County-Sector Growth & 0.011 & 0.026 & 0.010 & 0.024 & 0.032 & 0.028 & 0.038 & 0.035 & 0.037 & 0.033 \\
\hline $\begin{array}{l}\text { County Population } \\
\text { Growth }\end{array}$ & 0.019 & 0.019 & 0.021 & 0.021 & 0.023 & 0.024 & 0.026 & 0.026 & 0.029 & 0.028 \\
\hline Log Per Capita Income & 3.262 & 3.249 & 3.280 & 3.262 & 3.300 & 3.303 & 3.339 & 3.336 & 3.377 & 3.374 \\
\hline Log Population Density & -1.245 & -1.223 & -0.866 & -0.984 & -0.775 & -0.763 & -0.501 & -0.580 & -0.404 & -0.426 \\
\hline Hispanic Enrollment & 0.039 & 0.041 & 0.045 & 0.043 & 0.049 & 0.048 & 0.053 & 0.051 & 0.055 & 0.056 \\
\hline
\end{tabular}


Table B9. Hotelling $T^{2}$ tests by propensity score quintile.

\begin{tabular}{lccc}
\hline Quintile & $T^{2}$ statistics & F-test statistics & p-value \\
\hline First & 713.56 & 35.63 & 0.000 \\
Second & 429.27 & 21.46 & 0.000 \\
Third & 420.16 & 21.00 & 0.000 \\
Fourth & 853.77 & 42.68 & 0.000 \\
Fifth & $2,508.51$ & 125.39 & 0.000 \\
All & $1,390.11$ & 69.50 & 0.000 \\
\hline
\end{tabular}


Appendix C: Definitions of broad sectors, industry skill, and industry labor intensity.

\section{C.1. Definitions of Broad Sectors}

Throughout this paper, regressors are measured at different levels of industry aggregation. The process of matching is performed at the broad sector level, which are defined based on two-digit NAICS classifications. These classifications are designed to match as closely as possible the former SIC classifications and are reported in Table B1.

[Table $\mathrm{C} 1$ here]

\section{C.2. Construction of the Measure of Industry Labor Intensity}

Labor intensity for each industry is based on coefficients from the U.S. Input-Output (IO) Benchmark Tables 2002 (http://www.bea.gov/industry/index.htm\#benchmark_io). The labor intensity coefficient is defined as the share of compensation of employees (wage bill) in total industry output. Compensation of employees includes wages and salaries and their supplements. Total industry output is the sum of the products consumed by the industry, compensation of employees, taxes on production and imports less subsidies, and gross operating surplus.

\section{C.3. Construction of Industry Skill}

Each industry is assigned a skill intensity based on the weighted average of educational attainment of workers in that industry, using the Current Population Survey for 1994. This year was chosen since this is the first year in which the nativity (place of birth) of respondents is reported. For each industry, the percent of workers with less than a high school education (LTHS), a high school education (HS), some college (SCOLL), college degree (COLL), and graduate education (GRAD) is calculated. The regressor HigherEducation is the share of workers in the firm's industry with some college education or higher. 
Table C1: Definitions of broad sectors based on 2-digit NAICS classifications.

\begin{tabular}{ll}
\hline Sector & Included \\
& 2 -digit \\
& NAICS \\
\hline Agriculture and Natural Resources & 11,21 \\
Construction & 23 \\
Manufacturing & $31-33$ \\
Transportation and Utilities & $22,48-49$ \\
Wholesale Trade & 42 \\
Retail Trade & $44-45$ \\
Financial Activities & $52-53$ \\
Information & 51 \\
Professional and Business Services (includes temporary services) & $54-56$ \\
Education and Health Services & $61-62$ \\
Leisure and Hospitality & $71-72$ \\
Other Services & 81 \\
(includes private household, laundry, and repair and maintenance services) & \\
\hline
\end{tabular}




\section{Appendix D: Robustness Analyses}

The purpose of this Appendix is to describe a number of alternative specifications that were estimated in order to test the robustness of the results discussed in the text. Row 1 of Table D1 contains the parameter estimate, standard error, and marginal effect on the firm's hazard that results from employing undocumented workers, based on specification (A) in Table 2 of the text.

Although we include some geographic indicators that might affect a firm's survival, such as population density and county population growth, there may be additional, unobserved geographic factors that affect a firm's performance, or where undocumented workers locate. The second row in Table D1 presents the effect of including county fixed effects to the estimation. The coefficient is within a standard deviation of the baseline, suggesting that the geographicspecific regressors included in the baseline estimation are sufficient to capture county-specific variations that might affect firm survival.

\section{[Table D1 here]}

The definition of treatment is arguably arbitrary. The third row of Table D1 contains the result from repeating the baseline analysis using a different, more restrictive, definition of treatment. In addition to requiring a firm to have employed undocumented workers at least fifty percent of the time after first employing undocumented workers to be considered "treated," we also require that when a firm does employ them, at least five percent of the firm's workforce is undocumented. The estimated marginal effect is slightly smaller, but not so much as to change the conclusions.

A subset of workers classified as undocumented for this analysis reports as their SSN what is known as an Individual Tax Identification Number (ITIN). The pattern of digits identifying a number as an ITIN is described in Appendix A, but suffice it to say that it is in 
these numbers we have the strongest confidence in having identified an undocumented workers - workers who are clearly using an illegal form of work authorization. The fourth row in Table D1 restricts the identification of undocumented workers in a firm to those only if they are using a ITIN number as their SSN. As might be expected, the results are stronger (more negative), but not materially different from the baseline estimates. The similarity in estimates further validates the identification of other workers using worker-generated invalid SSNs as "undocumented."

Recall that in the baseline estimation, we rejected workers as undocumented if they had a SSN that looked like it was generated by the employer (e.g., all one number, repeated; equal to the employer ID; or the same for all workers in the firm). We speculated that these numbers were the result of sloppy or lazy bookkeeping. However, there is a possibility that firms resort to this type of record keeping when they employ undocumented workers as they expect the worker to stay only a short time and don't want to bother even asking for valid identification. If this were the case, workers using employer-generated invalid SSNs should also be included in the analysis as undocumented workers. The last row of Table D1 contains the answer to this question -- the coefficient is positive, increasing a firm's hazard. This is suggestive that the appearance of employer-generated SSNs is reflective of firm behavior correlated with bad performance, as these firms are much more likely to exit sooner, and that it is appropriate to exclude these workers from the analysis.

A last test of robustness is not contained in Table D1, but will merely be described here. It might be the case that the difference in hazard rates across treated and untreated firms is the result of some underlying production/employment dynamic. To test this, we estimated a standard regression (OLS) of average employment growth since treatment (excluding the 5 quarters before death, since all firms' employment levels are extremely erratic right before they 
die). As it turns out, there is no significant difference in average employment growth between treated and untreated firms, implying that the survival results are not masking some other underlying employment dynamic.

Table D1. Baseline and robustness results for overall impact on hazard (specification A). Coefficient on $U N D O C$ (standard error)

Testing Various Specifications of the Cox Hazard Model:

(1) Baseline (see results in Table 2) [marg. effect on hazard]
$[-0.1893]$
(2) Baseline, including county fixed effects
$-0.2418 * * *$
$(0.0609)$
$[-0.2147]$

(3) Baseline, treated only if share of $U N D O C \geq 5 \%$, in at least $50 \%$ of

$-0.1735^{* * *}$ quarters observed

(4) Baseline, undocumented worker designation limited to workers with invalid SSNs conforming to numeric pattern of an ITIN

$-0.2345 * * *$

$(0.0967)$

$[-0.2346]$

(5) Baseline, undocumented worker defined as one who has an invalid SSN that appears to be firm (rather than worker) generated

$0.6100^{* * *}$

$(0.0617)$

[0.8404]

Note: The baseline specification is based on the following definitions: (1) an undocumented worker as one who has an invalid SSN that appears to be worker (rather than firm) generated; (2) a treated firm is one that employs at least one undocumented worker in at least $50 \%$ of the quarters observed after initial undocumented worker employment; and, (3) a non-treated firm is one that employs an undocumented worker in fewer than $20 \%$ of the quarters observed. 